\title{
Exploring the Use of Social Media and Its Effect on Policy in Community Colleges
}

\author{
S. Dianne Davis \\ West Virginia University
}

Follow this and additional works at: https://researchrepository.wvu.edu/etd

\section{Recommended Citation}

Davis, S. Dianne, "Exploring the Use of Social Media and Its Effect on Policy in Community Colleges" (2014). Graduate Theses, Dissertations, and Problem Reports. 644.

https://researchrepository.wvu.edu/etd/644

This Dissertation is protected by copyright and/or related rights. It has been brought to you by the The Research Repository @ WVU with permission from the rights-holder(s). You are free to use this Dissertation in any way that is permitted by the copyright and related rights legislation that applies to your use. For other uses you must obtain permission from the rights-holder(s) directly, unless additional rights are indicated by a Creative Commons license in the record and/ or on the work itself. This Dissertation has been accepted for inclusion in WVU Graduate Theses, Dissertations, and Problem Reports collection by an authorized administrator of The Research Repository @ WVU.

For more information, please contact researchrepository@mail.wvu.edu. 
Exploring the Use of Social Media and Its Effect on Policy in Community Colleges

S. Dianne Davis

Dissertation submitted to the

College of Education and Human Services

at West Virginia University

in partial fulfillment of the requirements for the degree of

Doctor of Education in

Educational Leadership Higher Education Administration

Terence C. Ahern, Ph.D., Chair

Ernest Goeres, Ph.D

Ugur Kale, Ph.D

Rebecca Phillips, Ph.D

Andrea Weber, Ed.D

Morgantown, West Virginia

2014

Keywords: social media, FERPA, Facebook, LinkedIn, Twitter, GooglelPlus+, student teacher communication 


\section{ABSTRACT \\ Exploring the Use of Social Media and Its Effect on Policy in Community Colleges Shirley Dianne Davis}

The use of online social media websites has grown exponentially in past years. Recent studies show faculty use of social media is also growing. This study examined how faculty are using social media websites with students and if they are aware of issues that violations of the Federal Educational Rights and Privacy Act could cause. The research questions were: How are faculty using social media for teacher-student communication; Are there privacy concerns faculty should be aware of because of the Federal Education Rights to Privacy Act; and what social media is being use by faculty to communicate with students. Participants were faculty, both full time and adjuncts, in a Mid-Atlantic community college that also offers four-year degrees. A modifiedDelphi was used to collect the data. This study was looking to identify commonalities in faculty use of social media. The first survey was sent to all faculty at the institution. A second survey was sent to all those that responded to the original survey. The third and final "survey" was an email chat with faculty that answered yes to two out of five questions regarding the use of social media currently with students. Findings indicate that faculty are using social media to communicate with their students; faculty are aware of FERPA but they do not always know what constitutes a FERPA violation. The outcomes of this study can help administrators make more informed decisions regarding policies concerning faculty and student use of social media. 


\section{Acknowledgements}

\section{Dr. Terence C. Ahern}

I would like to thank my Chair, Dr. Terence Ahern for taking my "case" after many others had left the University. He always had faith in me that "I could do it" and always kept a light hearted sense of humor when encouraging me through this process. He was GREAT.

My Committee

Dr. Ernest Goeres, who was also my professor. He was an inspiration with his positive attitude. Dr. Andrea Weber who was assigned to be my mentor when the University was in transition. She read and reread and corrected many drafts until I had an official Chair. Dr. Rebecca Phillips, a dear friend and colleague who agreed to serve on my committee. She always had kind encouraging words for me and she's great with punctuation. Dr. Ugur Kale, who was very helpful and supportive. I was very happy with each and every one that helped me through this process.

My Children

My daughters, Laura Watts and Michelle Demetro were always encouraging. My son Daniel Davis has been the one that lived with me and had to suffer through papers all over the house and endless hours of fending for himself. He was responsible for keeping me grounded when I lost my common sense.

My Dad and Mom

Andrew Davis, my 87-year old father, at every opportunity asked me if I was Dr. Davis yet. He was so proud that I was working on my degree. My mother, Betty Locke, passed before I could finish but I spent many hours working on my research while sitting with her when she was ill.

My Colleagues

As my college president, Dr. Marie Foster-Gnage was always encouraging and she and our Academic Vice President, Dr. Rhonda Tracy, worked it out so I could have a three-course release to work on my dissertation. They were always asking how I was doing and when would I finish. John Gorrell, my boss at the Jackson County Center where I work, was always encouraging and always had something funny say to brighten the day.

David Lancaster and Cindy Gissy, two colleagues who had finished their dissertation before me, helped me through the process by telling me what to expect and constantly telling me "if there is anything I can do" to help me.

My Friends

Torie Knight, who is on this dissertation journey with me, always encouraged me. We had a plan to complete together. She helped me keep focused and knowing she was there with and for me kept me confident. Violet Mosser, my very, very good friend, was always there to encourage me. We had many trips with students when she attended conference sessions while I stayed in the hotel room and wrote. Lauriel Edwards, our Division Secretary, but so much more than that has encouraged more than she will ever know. Many, many, many friends have encouraged me and marveled at the fact that I am sixty-five and became Dr. Davis. 
Table of Contents

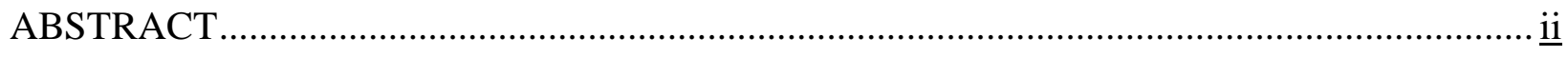

Acknowledgements ..........................................................

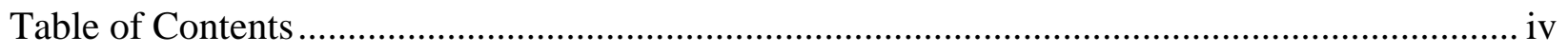

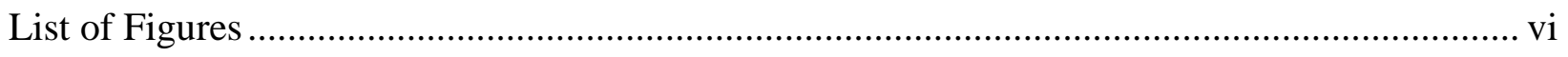

Figure 1. Time Line of Social Media Created by boyd and Ellison (2007) .............. .. vi

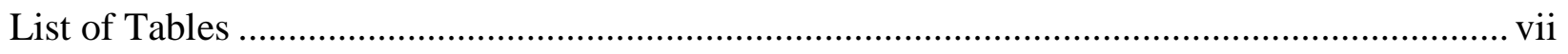

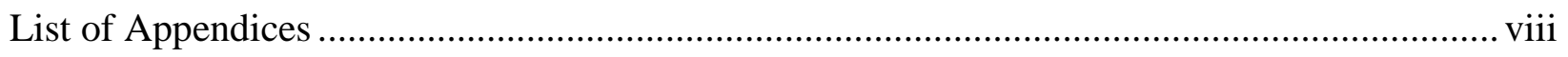

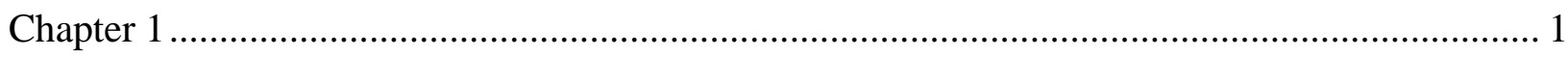

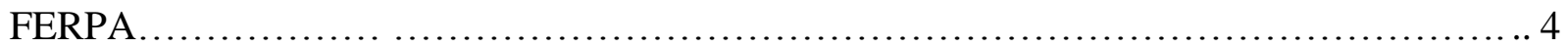

Purpose of the Study ..................................................... 5

Research Questions ........................................................ 5

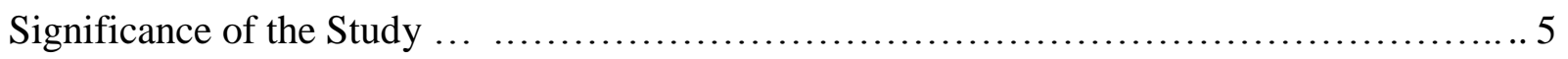

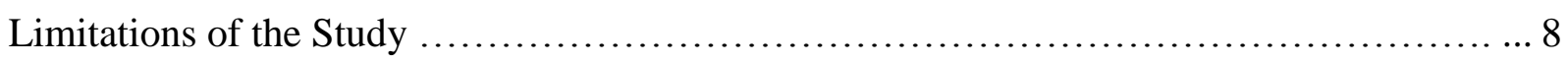

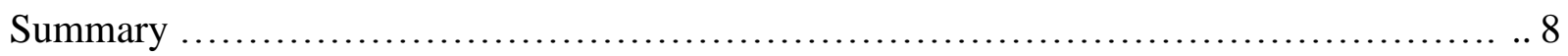

Glossary ... .............................................................. 10

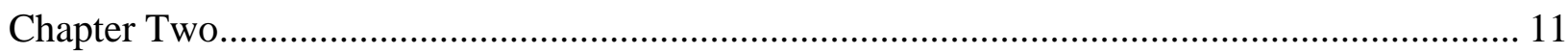

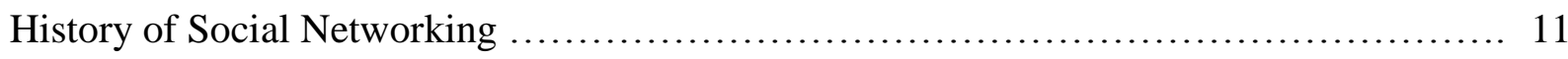

Faculty and Social Media in Higher Education .................................. 14

Faculty, FERPA, and Social Media ......................................... 16

What is Missing from the Literature? ...................................... 19

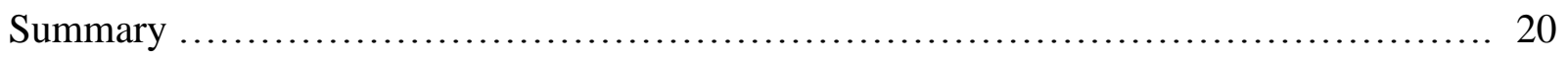

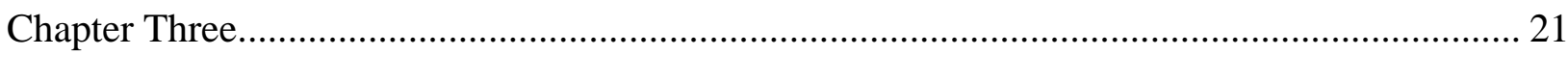

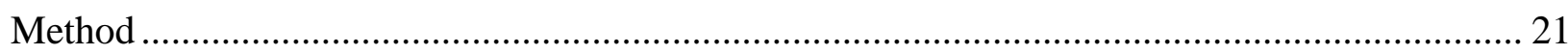

Participants ........................................................... 21

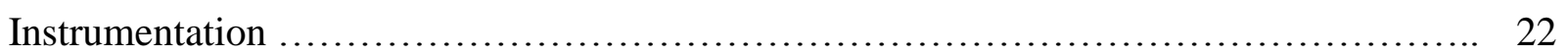

Data Collection ........................................................ 25

Guarantee of Anonymity and Confidentiality ................................... 27

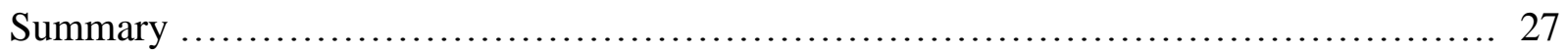

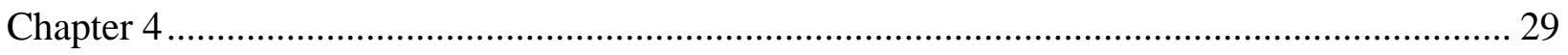

Faculty Characteristics ................................................. 29

Survey Number One - Exploring Social Media ................................... 30

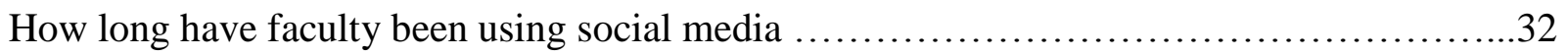

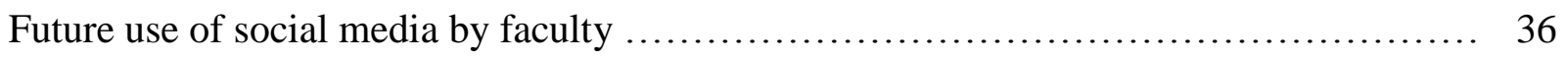




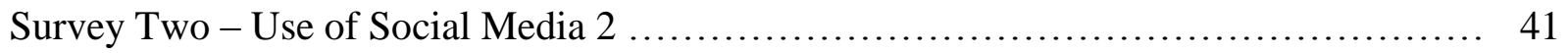

Faculty and students using social media ............................................ 46

Policy, FERPA and social media .................................................. 47

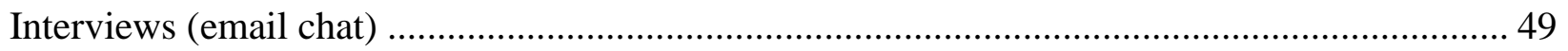

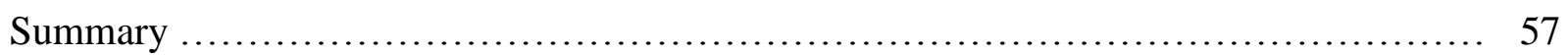

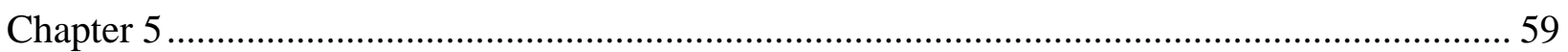

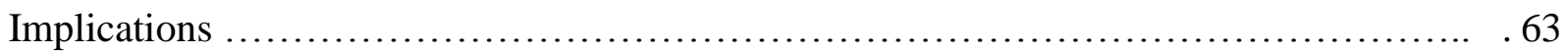

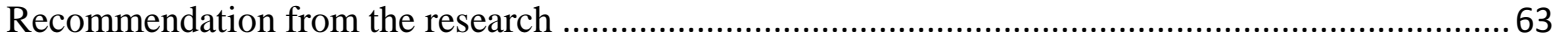

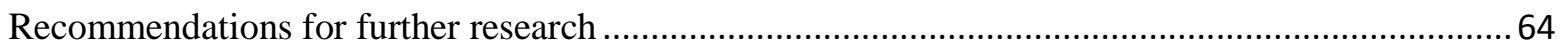

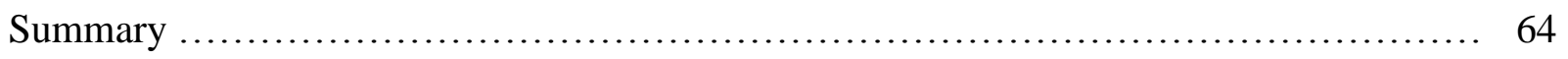

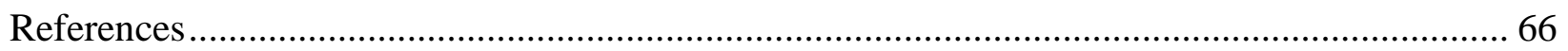

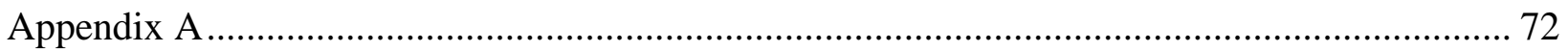

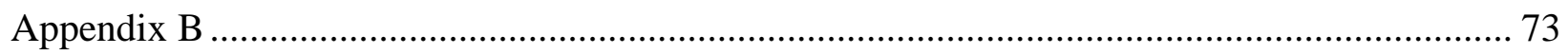

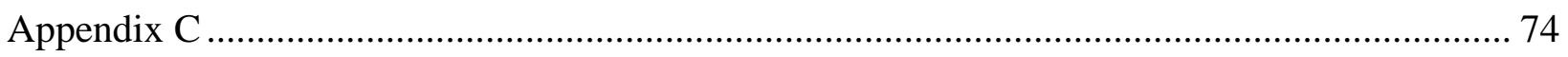

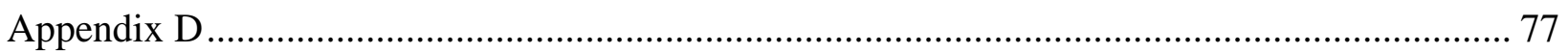

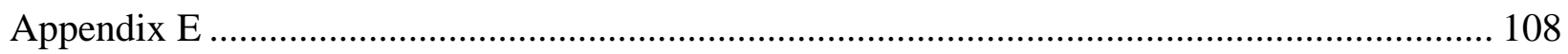




\section{List of Figures}

Figure 1. Time Line of Social Media Created by boyd and Ellison (2007) ............ 13 


\section{List of Tables}

\begin{tabular}{|c|c|}
\hline Table 1 Faculty Demographics (Survey One) & 31 \\
\hline Table 2 How Often Are Faculty Using Social Media (Survey One) & 32 \\
\hline Table 3 How Long Have Faculty Been Using Social Media (Survey One) & 33 \\
\hline Table 4 Faculty and Student Interaction on Social Media (Survey One) & 34 \\
\hline Table 5 Future Use of Social Media (Survey One) & 37 \\
\hline Table 6 Additional Comments Made by Facultyfor Social Media (Survey One) & 39 \\
\hline Table 7 Faculty Demographics (Survey Two) & 43 \\
\hline Table 8 Faculty Use of Social Media (Survey Two) & 45 \\
\hline Table 9 Faculty and Students Using Social Media (Survey Two) & 48 \\
\hline Table 10 Policy, FERPA and Social Media (Survey Two) & 49 \\
\hline Table 11 Interviews (Chats) & 50 \\
\hline
\end{tabular}




\section{List of Appendices}

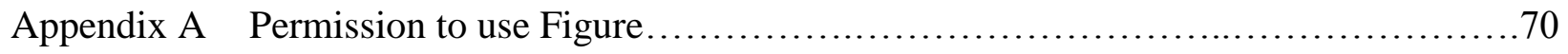

Appendix B Permission to use Survey .................................................. 71

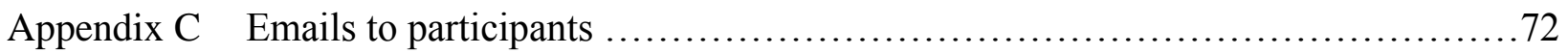

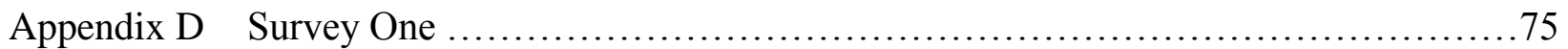

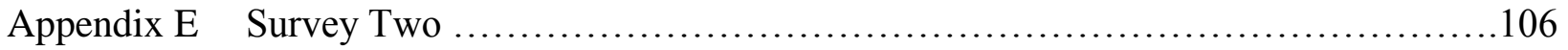




\section{Chapter 1}

Social media is here to stay. With the advent of social media such as Facebook, LinkedIn and Twitter, faculty in community colleges have the opportunity to share ideas with colleagues, friends, family and anyone with a social media link in a very public manner. The availability of these rapidly expanding social connections brings questions for those using social media. Rules already in place such as the Family Educational and Privacy Rights Act (FERPA) might apply to what faculty are posting on social media sites.

Many colleges offer classes and often entire degree programs in an online format. Most of these programs are conducted by using a Learning Management System (LMS) or a Course Management System (CMS) such as Blackboard or WebCT. These are secure password protected systems that are housed within the institution and are only accessible to the student and faculty. These systems are internet-based to facilitate anytime, anywhere access to learning content and administration (Black, Beck, Dawson, Jinks \& DiPietro, 2007). Chen and Bryer (2012) explain,

CMS Wikies cannot be shared with viewers outside of the institutions; learning portfolios cannot be maintained over multiple semesters. The connectivity and openness are lost to the present formal learning environment given the lack of access to external social opportunities. (p. 89)

Diaz (2011) writes, “Alongside the growth of e-learning, higher education has witnessed the explosion of cloud-based or Web 2.0 technologies, a term that refers to the vast array of socially oriented, free or nearly free, web-based tools," (p. 95). Add to this the potential for 
engaging students by using commercial systems such as Facebook, LinkedIn, and Twitter and the privacy issues become even more important.

When faculty sends comments or corrections regarding an assignment to a particular student but also includes the rest of the class in the e-mail - this is a violation of the students' privacy rights as this makes other students aware of their grade (FERPA, 2012).

The explosion of use of online social media between faculty and students creates great potential for FERPA violations and the potential for job loss of the faculty. Carter, Foulger and Ewbank, (2008) state,

Those of us who are committed to the field of education cannot stand idly by and allow careers to be jeopardized. At the same time, we must not be deterred from exploring new possibilities and discovering appropriate uses of these powerful tools. (p. 684)

Social media sites are defined by boyd and Ellison (2007) as, “web-based services that allow individuals to:

- construct a public or semi-public profile within a bounded system,

- articulate a list of other users with whom they share a connection,

- view and traverse their list of connections and those made by others within the system.

Most social media sites have a "user" profile that includes basic personal information. Further special interests may be added so members can connect with others that share common interests. It is easy for faculty and students to interact with one another. A survey conducted by 
Moran, Seaman, and Tinti-Kane (2012) for Pearson through Babson Survey Research Group, of faculty in higher education, found $80 \%$ of college and university faculty were using social media in one form or another. "The use of social media between faculty is fluid and evolving. The mix of sites being used is changing over time - in 2011 Facebook was the most visited site for faculty professional purposes; by 2012 this has been replaced by LinkedIn" (p. 5). The Pearson survey shows nearly two-thirds of faculty visited a social media site within the past month for personal use and the rate goes to over $80 \%$ when those who use it less frequently are added (p. 7). Faculty use of social media for professional use is $44.7 \%$ (p. 11). Faculty using social media for teaching purposes was $33.8 \%$ (p. 16).

Faculty were not specific as to how they were using social media as part of their teaching. Sixty-four percent of faculty had concerns about privacy issues with social media but none expressed concerns regarding FERPA (Pearson 2012, P. 27). The Pearson survey did not inquire about faculty awareness of institutions policy regarding use of social media or FERPA concerns.

The use of online applications will continue to grow. The potential for using social media is staggering. There are currently 1.1 billion monthly active users of Facebook. If this were a country it would be the third largest country in the world. Daily users average 655 million (Facebook (2013). There have been over 554,750,000 million Twitter accounts opened in Twitter's history as of May 7, 2013, with 58-million tweets on average a day (Twitter (2013). There were 225- million LinkedIn members as of March 2013 with more than two professionals per second signing to join (LinkedIn (2010).

The survey conducted by Pearson Learning Solutions with Babson Survey Research Group (2012), found that "faculty are very aware of social media and considerable numbers of 
them use it regularly in their personal lives" (p. 5). This survey looked at the use of Facebook, LinkedIn, and Twitter as well as blogs and wikis. This study is interested in the interaction between faculty and students on the social media sites of Facebook, LinkedIn and Twitter.

What started out as a website for college students soon grew into a social media network of more than one billion users at the end of 2012. In just over a year, the site has added 250 million users as of December 12, 2012. Twitter added 325 million and LinkedIn added 80 million in the same time frame (aboutFacebook.com, about Twitter.com and aboutLinkedIn.com).

This rapid increase in the use of public online social media leads one to better understand the need for a study to determine how faculty are using social media and potential violation of the Family Educational Rights and Privacy Act (FERPA) while engaging with students in their courses.

\section{FERPA}

According to the Federal Register, The Family Educational Rights and Privacy Act (FERPA, 2012) is:

a federal law that protects the privacy of communication between students and teachers regarding their educational records, whether as part of a class or during advising. Generally, schools must have written permission from the parent or the eligible student before they can release any information from a student's educational record other than directory information such as name, address, telephone number, date and place of birth, honors and awards and dates of attendance. Eligible students and parents must be told and given a reasonable 
amount of time to request that the directory information not be given out should they so choose. (US Department of Education, p. 75604)

\section{Purpose of the Study}

The purpose of this study was to examine the use of online social media by faculty in community colleges and their awareness of privacy issues regarding FERPA. This exploratory study investigated how community college faculty were using social media for teacher-student communication, what technologies were being used, and whether faculty were aware of FERPA issues that could be violated by the use of social media.

The conclusions of this study will provide all stakeholders with additional research regarding policy decisions, potential FERPA violations, and the use of social media by faculty in the community college system.

\section{Research Questions}

The following questions guided the research of this exploratory study:

- RQ1 How are faculty using social media for teacher-student communication?

- RQ2 Are there privacy concerns faculty should be aware of because of the Federal Education Rights to Privacy Act?

- RQ3 What social media is being used by faculty to communicate with students?

\section{Significance of the Study}

Understanding the significance of social media use by faculty and how it can be both helpful and problematic is critical to a number of stakeholders. Information regarding policy and FERPA rights for social media use by faculty is also critical. 
First, faculty can benefit from the use of social media as it is a means of connecting with students and can also be used to share information about coursework. One study conducted by Pearson Learning Solutions and Babson Research Group (2012) regarding faculty use on Facebook reported that $90 \%$ of faculty interviewed mentioned that Facebook provided an open line of communication between faculty and students. A responder for the Sturgeon \& Walker survey (2009) was quoted as stating, "Anything that helps students feel more comfortable in the classroom environment, where they can feel a connection with their instructors, opens the door to better understanding, better communication, and better learning" (p. 4). However, faculty need to be aware of pitfalls of using social media. Sturgeon \& Walker also found that seventy-five percent of faculty were concerned about the balance between being a teacher and being a friend to their students (p. 4). Faculty also need to be sure to protect the privacy of students' education records. According to the Federal Register, FERPA represents the floor for protecting privacy, not the ceiling. They recommend the authorized representative [in this case, faculty] take protecting privacy to the greatest extent possible (Dec. 2011, p. 75649).

Second, students can benefit from faculty use of social media as it can assist in building a relationship with faculty that can potentially help with student learning. Students appear to be more willing to communicate with their instructors if they already know them through the use of Facebook [or other social media]. Sturgeon and Walker (2009), suggested that this relationship of in-class interaction between student and instructor might be enriched based merely on the use of a social network (p. 9). The University of Nebraska at Lincoln used student Facebook groups (posted by student employees) to build interest and momentum for service-learning and other student events, making them feel less institutional (Workman, 2008, p. B12). 
It is important to note that the communication between faculty and students is different in the face to-face classroom than the interaction with faculty and students on social media. As long as a student has not requested to have their directory information withheld, conversation in the classroom is not considered privileged information. Even the discussion of grades is acceptable because students' grades have not been recorded yet (Federal Register, 74812). Faculty need to be more cautious when using social media because someone other than the student may see the shared information. Rey Junco (2012) writes in his Social Media in Higher Education blog:

Time and time again, Facebook has been notorious for tricking users into sharing more of their personal information. In 2007, Facebook launched a system named Beacon that allowed non-Facebook websites to include a script that would send user information back to Facebook. A user didn't have to be logged in to Facebook for their information to be collected from a third-party site, nor were the users even informed it was happening. (Social Media in Higher Education, $[\mathrm{B} \log ])$

Finally, school administrators can benefit by determining what kind of policy might be needed to protect their organizations. "The attention that Facebook has generated has given college administrators plenty of incentive to consider whether their institutions should issue warnings about the site" (Brock \& Young, 2006, p. 37). Administrators can also learn the advantages of using social media for recruitment, retention and marketing purposes. At Mercyhurst College in Erie, Pa., administrators sent "a call to action," asking faculty and staff to join Facebook in the hopes that it would have a "norming influence" on content (Lupsa, 2006, para. 20). 
It is important that those in higher education understand the vast possibilities available to them by using social media. Ten years ago a transcript of an important event might be published or eventually put on the web. Today it is instantaneous (S. Johnson, 2009, p. 2). These sites make it possible for all stakeholders to interact with one another at any given point in time.

Research must be done in order for:

- School administrators to determine policy decisions;

- Faculty must understand the potential for benefits but also repercussions of sharing personal information with students;

- Faculty and Administration need to understand the importance of protecting students' rights and not violating FERPA.

\section{Limitations of the Study}

A possible bias exists because of the researcher's use of social media and online instruction. The potential for this bias will be limited by the use of an established survey instrument. The study is limited by the use of an established survey instrument. The study is also limited in that it is exploratory of a particular type of institution of higher learning, the community college.

\section{Summary}

The use of social media by faculty in community colleges is growing rapidly. There is research to show faculty are using social media but very little research has been done to show how faculty in community colleges are using social media with their students and whether or not they are aware how policy such as FERPA affects the use of social media. While the possibilities for interaction between all participants in community colleges using social media are great, there 
is also potential for problems within the college arena. The more information we can accumulate about the use of online social networking sites by faculty and students in community colleges, the more informed decisions we can make when developing policies and making recommendations to faculty and students regarding their use of social media.

Further research regarding faculty use of social media can potentially offer better informed decision making for administrators in setting social media policy; offer faculty more ideas for teaching resources and what they should and should not do when posting on social media; and help other faculty connect with students to improve the learning environment by engaging their students. This study's intent was to facilitate a better understanding of faculty and student use of online social media and the need for guidelines regarding privacy concerns of faculty and student interactions in social media use in community colleges. 


\section{Glossary}

Privileged Communication is communication between a faculty member and student that is not expected to be shared with anyone other than the faculty member.

Potentially Identifiable Information is a FERPA term meaning any information that can identify a student to the extent that others know which courses they are taking (Federal Register, 76(232) 75604-75660).

FERPA, Family Educational Rights and Privacy Act, is a set of rules designed to protect the privacy rights of students regarding their education. Once a student becomes a college student even if they are not yet 18, parents no longer have the right to access their educational records. There are exceptions such as if the student is still claimed on their parents tax return (Federal Register, 76(232) 75604-75660).

Social Media, as defined by boyd and Ellison is web-based services that allow individuals to construct a public or semi-public profile within a bounded system, articulate a list of other users with whom they share a connection, and view and traverse their list of connections and those made by others within the system ( Journal of Computer-Mediated Communication 13(1), 210230). 


\section{Chapter Two}

Because social media such as Facebook, Twitter and LinkedIn became available to anyone over a certain age with an email address, there is the potential for interaction between college faculty and students. This can have a positive interaction, which can bring about relationships that lead to immediacy, which in turn can bring about higher graduation rates. On the other hand the use of social media in higher education can be seen by others as a negative because of the many potential problems such issues as the Family Educational Rights and Privacy Act (FERPA).

It is well known that faculty were using social media because surveys such as those completed by Pearson (2012) and Magna (2011). However those surveys did not show the extent of faculty use or the kind of content being posted. Nonetheless, the use of social media has tremendous potential for connections between faculty and students or connections between faculty and other faculty. However using social media also has the great potential for negative consequences if what is posted should violate the rights of students. This could result in a faculty losing a job based on what they have posted. Because of the lack of knowledge as to how faculty were using social media, this study looked at faculty's use of social media and faculty's awareness of FERPA. This study began with a history of social networks, history of social media, what we know about how faculty is using social media now, and the potential for FERPA violation. This study focused on faculty in the community college setting.

\section{History of Social Networking}

Social networks have been around almost from the beginning of time. Most of us have many different "social" networks that we don't even think of as networks. The faculty members we served on committees with, our students in the classroom, friends and family we have met 
only occasionally is still a network. The dictionary definition of network is, "the exchange of information or services among individuals, groups, or institutions; specifically the cultivation of productive relationships for employment or business" (Merriam-Webster, 2013). Anytime two or more people are connected with a similar interest a network has formed.

These social networks can serve a variety of purposes such as opportunities for advancement; resources one might not have known were available; knowledge about something people are interested in and even mentors. People involved in building and maintaining informal relationships have a tendency to be more satisfied with their careers (Wolff \& Moser, 2009; Mabrouk, 2009). We have grown from face to face networking to the World Wide Web where networking is now done by connecting with one another on one of many social media.

Social media are Internet based sites where individuals can communicate with one another by friending, following, tweeting, and connecting. Boyd and Ellison (2007) define social media as:

Services that allow persons to build a public or semi-public profile within a bounded system where they create a list of other users with whom they share a connection, and they can then view their list of connections and those made by others within the particular system they are using. Each social media has its own unique specifications. The common thread between most sites includes a profile; a "friends" list with people with whom they have some kind of a personal connection; a way for users to leave messages or comments on other people boards; and a way to create private messaging. Each social media may have different privacy settings and may also be designated for different uses. (boyd \& Ellison, 2007, P. 210) 
Social media is referred to as the fingerprints of the twenty-first century. It is being used to track criminal activity, measure brand advertising, screen job applicants and investigate present employees Marissa, 2007, 2010, Maryott, 2011, Boyd, 2011).

The first online social media was attributed to Sixdegrees.com in 1997. The site attracted millions of users at first but after signing up and accepting their friends' request, users complained there wasn't anything else for them to do, so by 2002 it was no longer in use. Since the introduction of Six Degrees, there have been rapid expansions of social media sites. Ellison boyd (2007) have created a timeline that incorporates most of the more popular sites.

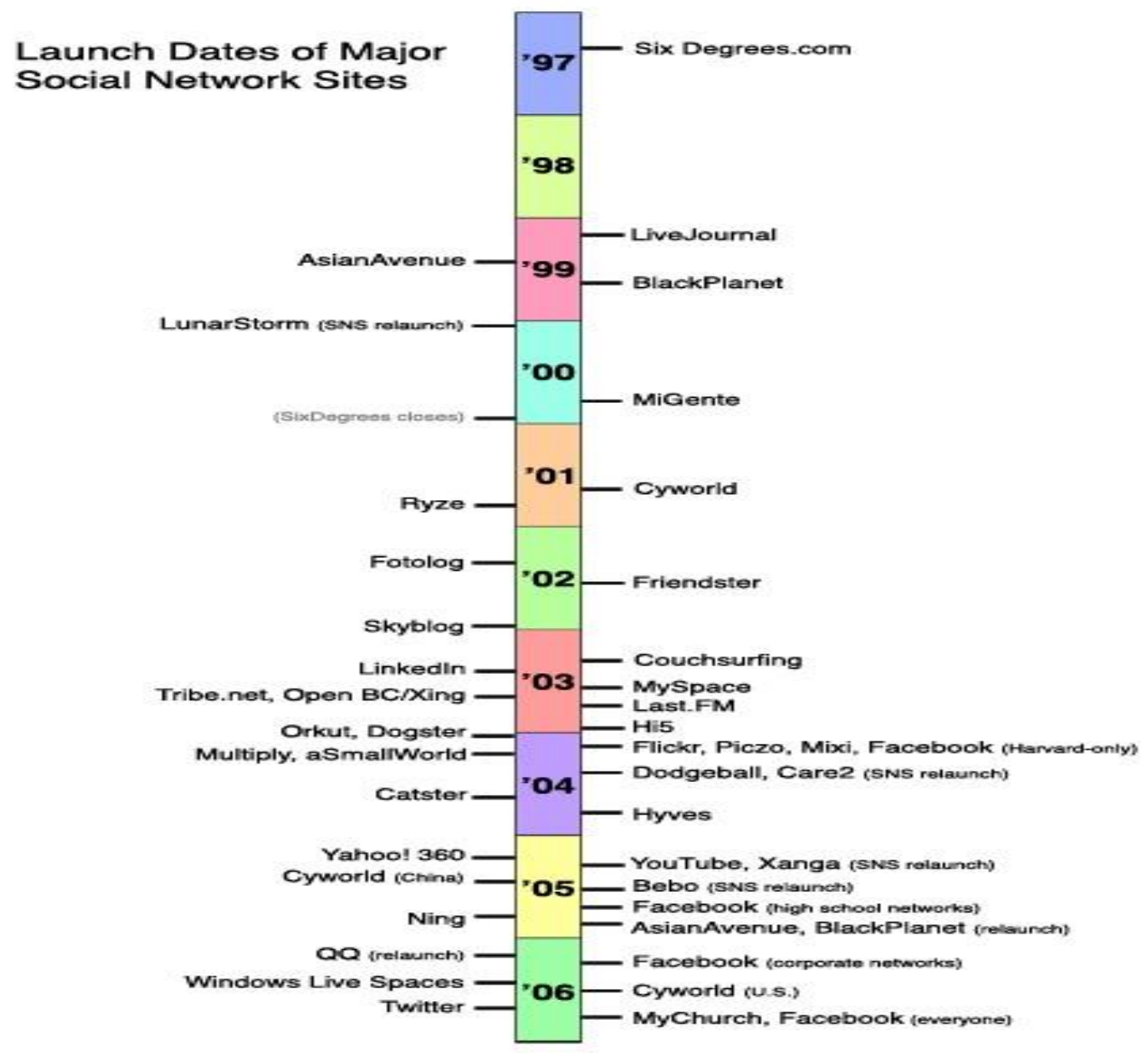

Figure 1, Time line of social media. Reprinted from Social network sites: Definition, history and scholarship, by d. m. boyd \& N. B. Ellison, 2007, Journal of Computer-Mediated Communications 13 (1), 210-230. Reprinted with permission (Appendix A). 
The most popular social media, and the ones still growing, include Facebook, Twitter and LinkedIn. The first and largest, Facebook, started out as a website for college students and it soon grew into a network of over a billion users as of December 31, 2012 (Facebook (2013).

Twitter, the second largest social media site is a "real-time information network" that connects one to stories, ideas and people by blogging in 140 character "tweets" as the posts are called. One doesn't have to "tweet" to receive benefit from Twitter as it still provides access to information of interests. At the end of December 2012, Twitters site boasts over 500 million users (Twitter (2013).

The third site, LinkedIn, as of December 31, 2012, is considered the largest professional network on the internet with more than 200 million members in over 200 countries and territories. This social media officially launched in 2003 with 4,500 members at the end of the first month. Once connected to LinkedIn, one can search extended networks of contacts and discover connections to companies they might want to partner with. LinkedIn is considered the largest provider of networking tools and now participants can form groups such as "The Teaching Professor" to join with others to discuss teaching techniques or ask questions about posting issues on social media (LinkedIn (2013).

\section{Faculty and Social Media in Higher Education}

A survey published by Pearson Learning Solutions and Babson Survey Group (2012) found faculty are "very aware of social media and considerable numbers of them use it in their personal lives".

The purpose of the Pearson/Babson study was to examine faculty use of both personal and professional use of social media. The survey reported the following statistics: 
Eighty percent of faculty access social media at least once a month. Forty-five percent use social media for professional reasons on a monthly basis. LinkedIn was used the most often for professional use (24\%) with Facebook (19\%) and Twitter (5\%) last. Just over one third of faculty reported using social media in their teaching. (pp. 1-48)

The potential is great for faculty in higher education to post inappropriate materials that end up being seen by people for whom it was never intended. Some postings to social media have caused issues that have come back to haunt teachers including:

A teacher who asked her students to post profiles so their future students might view them only to find one gruesome post by a student that affected the way he was thought of for the rest of the course. Another teacher was fired from her position as a high school art teacher because her partner, a professional photographer, had posted nude pictures of her on his site. A middle-school teacher lost his job because of information deemed "inappropriate" by the teacher's school board and then another teacher was investigated by her employers because she posted critical comments of the parents of her children. (Carter, Foulger and Ewbank, 2008, p. 681-685)

Faced with the possibilities of faculty members posting items deemed inappropriate by others, some states are looking at state statutes to limit what state employees, i.e., public educators can and cannot post on social networking sites. While few states have enacted such statues, Estrada (2010) has discovered most districts do recognize that a faculty members use of social media can cause a problem. According to Estrada, Missouri state legislator Jane Cunningham proposed a bill "prohibiting teachers and students from having online friendships" (p. 288). Estrada also reports California proposes to enact a statue prohibiting public school 
teachers from communicating with their students using social media. Florida, Colorado, Tennessee and Massachusetts are among the states that have released or suspended teachers over the content of their MySpace pages (Shapira, 2008, para 5).

Ball State University and DePaul have established guidelines for their faculty's use of social media. DePaul's policy basically instructs faculty how to use the social media while Ball State is more specific regarding privacy issues and actually states in the policy that privacy does not exist in the social media world (Ball State University, 2009, DePaul University, 2006).

\section{Faculty, FERPA, and Social Media}

Hand (2011) writes, "University professors are increasingly expected by students to appear 'accessible' or at least 'human'. Faculty and administrators often use social media as a means to engage with students and promote transparency" (para. 9). Hand continues, "Crossing previously marked professional and personal boundaries is all too easy in social media, where informal comments take the form of permanent records" (para. 11). Schwartz (2010), an assistant professor in Pennsylvania that shares a Facebook site with her students', states,

"I now see Facebook as part of the larger commons, a space in which we stay connected. Facebook, instant messaging, and the like, keep my metaphorical office door open. And that increases the potential for real-time, face-to-face conversations that are rich with connection, depth, risk-taking, and growth. (p. 42.)

Sites like Facebook have their own "Terms of Service" that often maintain access to information posted online for years (Junco \& Chickering, 2010, p. 14).

Faculty have to be careful not to violate a student's rights by divulging information protected by the Family Educational Rights and Privacy Act (FERPA) regulations. FERPA is a 
Federal law enacted by Congress in 1974 to protect the privacy of students' educational records.

Schools that receive funds under applicable Federal programs from the U. S. Department of

Education must abide by this law. Educational records generally require written permission from the eligible student or their parents before educational information can be released (US Department of Education, 2011, P. 75604).

Revisions to FERPA went in to affect January 2, 2012 that help to clear up some of the disclosure concerns:

Directory information can be shared. Parents and students are given the opportunity to view the information and make corrections to the information and unless they sign a waiver starting the information is not to be disclosed then the directory information can be shared. Personally identifiable information (PII) is the information from the educational record that cannot be shared without consent by the student. There are two exceptions to this consent rule and those involve organizations conducting studies that benefit the school or school district and audits. (Federal Register, p. 75612-75613)

Colleges tend to err on the side of prevention when it comes to sharing student information because they do not want to risk losing federal funding by violating FERPA. The secretary of the Department of Education can "withhold further payments [Federal funding for students] under any applicable program (2011, 76 FR 75643). Talbert, (2008), writes in The Chronicle, about a professor at the University of Texas A\&M who was fired for violating FERPA when he posted the names of six students in his blog. The professor had included in his syllabus for the course, that anyone caught plagiarizing would be 
publicly humiliated, so he published the names of the students and he was fired (Wired Campus, np). According to Alexandra Rice (2011):

“Georgia Tech removed ten years of class work from its collaborative-learning Web sites (Swikis) following a student's complaint to the university that his name was listed on the Web site of a public course." The dean wrote a letter to faculty explaining, "Ferpa "prohibits the release of student names in connection with any particular classes in which they have been enrolled. Under the university's interpretation, that includes the Swikis, because students' names are listed on the Web sites.' (Wired Campus, np)

The Georgia Tech incident would be considered a violation of sharing publically identifiable information (2014) e-CFR. Title 34. SS 99.3)). Another issue can be privileged communications. Privileged communications are those communications shared between a faculty and student that are not directory information and should not be shared publicly without the students' written consent. Conversations in the classroom setting could be considered privileged as there is the perception the information is not going to go any further than the classroom.. FERPA does not, however, refer to privileged communication other than it is not a violation of FERPA to share information if a student reveals they are contemplating suicide or they are thinking about harming other students (T. Hughes (2000). P. 21).

Another area faculty need to be careful with privileged communication is during advising. Parents often come to advising sessions with the student or the student brings along a friend. Unless the student signs a waiver the faculty will be violating FERPA if he/she continues to advise the student in their presence (2011, US Department of Education). 
Violation of the following rules or exceptions could eventually cause issues for the college.

- How many faculty are going to ask for written consent before answering a question a student might ask them on Facebook that pertains to the students PII?

- Does the fact they are on Facebook and asking the question serve as consent?

- Will it really matter as FERPA penalizes the college and not the faculty member?

- If the college has written policy regarding a faculty's use of social media, then there might be recourse against the faculty member. Either way faculty do not want to violate FERPA as any negativity directed to a faculty member will still bring negative publicity to the college.

\section{What is Missing from the Literature?}

School rules from as early as 1872 (attributed to a posting in a Monroe County Iowa school house) would not allow a female to teach if she were married or if she participated in unseemly conduct. Male instructors could not go to the barber for a shave or their integrity was questioned. Teachers today have come a long way with what they can and cannot do in the educational realm but with the advent of social media they now have to be careful what they post as once something is created in the electronic environment it is often available for their peers, their administrators, their school boards, and their students to view.

While the use of social media is growing rapidly there is still a lot of confusion as to how college faculty can or should use them. Boyd and Ellison, 2007, are recommending further research be conducted to determine the who, the how and the whys of social media use (Future Research section, para. 1). While states and institutions are looking at the negative side of social 
media and the harm that can come from faculty posting inappropriate information, what about the positive side of faculty posting on social media? We still do not have an answer to the question of how most faculty are actually using social media and are they using them for classroom instructional purposes. Martin Hand (2011) would have us ask about the implications for the university,

The debate revolves around how social media might help build relationships between faculty and students, but then on the other hand will it lead to excessive informality that might compromise the teaching capacity of the faculty. He goes on to ask, "Should faculty be left to make their own professional judgment or should there be a more stringent set of intuitional policies"? (p. 10)

\section{Summary}

We know faculty use online social media sites. What we do not know is how faculty use social media. Do they use it for personal use only? Is what they share personally something that might get them into trouble with institution administrators? Do they use social media for teaching purposes? Do faculty allow students' access to their social media? There are still lots of questions to be answered regarding faculty's use of social media. This study looked at faculty's use of social media, including personal use, educational use, and faculty's awareness of FERPA or other privacy issues in the community college setting. 


\section{Chapter Three}

The purpose of this study was threefold. First, we wanted to examine how faculty are using social media to communicate with students in community colleges. Secondly, what were faculty's awareness of the impact of violations of the Family Education Rights Act (FERPA). Finally the researcher wanted to evaluate what kind of social media faculty were using to communicate with students.

Use of social media is increasing rapidly and while studies looked at the awareness of social media, they failed to determine how faculty and students were using the sites and if those faculty were aware of problems that might arise based on FERPA. This exploratory study sought to determine if faculty in community colleges were using social media for teacher-student communication; what technologies were being used by faculty to communicate with students; and were faculty aware of FERPA by using a modified Delphi method.

Stakeholders will benefit greatly from this information as it will open a window of opportunity to further educate those in higher education in the use of social media and aid them in preventing some of the potential problems that can arise such as law suits and loss of jobs as shown in previous chapters.

\section{Method}

\section{Participants}

The participants for this study were faculty from a mid-Atlantic Community College with a Carnegie Classification of Public, 4-year or above, Associate dominate with an enrollment profile of exclusively undergraduate four-year. The institution had an enrollment of approximately 3,900 students (Carnegie Foundation, 2012). There were 97 full-time faculty and 
between 175 and 250 adjunct faculty, depending on the semester, teaching at this institution .The institution offers certificates; associate degree programs; and is one of only thirty-four colleges in the nation to be accredited to offer baccalaureate degrees (Russell, 2010, p. 7).

Using a modified Delphi Method approach, surveys were sent to all faculty, both full time and adjuncts. The number of survey rounds depended on the information gathered in the previous survey.

\section{Instrumentation}

This study used a modified Delphi Method approach. The survey instrument used was a replication of a survey conducted by Magna Publications (Appendix B), via Faculty Focus in the spring of 2011 to over 1000 faculty members in higher education. The instrument had been used in 2010 to determine faculty use of the online social media Twitter and in 2011 Facebook and LinkedIn were added to the survey. Magna Publications is based in Madison Wisconsin. Magna produces seminars, publishes white papers, and Faculty Focus (FF), a newsletter that publishes articles on effective teaching strategies for the college classroom -both face-to-face and online (Magna Publications, 2012).

The questions asked in the Faculty Focus survey included information this researcher was seeking with the difference being this researcher was looking at community college faculty only and their awareness of privacy or FERPA issue. The researcher went into further depth in the second round of the survey to determine more specifically how faculty were using social media .

The questions asked in the Faculty Focus survey included the following:

1. What is your role in higher education?

2. How many years have you worked in higher education?

3. Which best describes your institution?

4. Do you allow the use of laptops and smart phones in your class room ? 
5. How often do you use the following social media tools?
a. Facebook
b. LinkedIn
c. Twitter

6. Approximately how long have you been using these social media tools?
a. Facebook
b. LinkedIn
c. Twitter

7. When you think about how you use social media, do you use these tools for PROFESSIONAL uses (such as with students or colleagues) or for PERSONAL use during your free time?

8. Have you ever "friended" a student on Facebook?

9. Have you talked to your students about managing their online reputations?

10. Despite the benefits of social media, problems can arise when the technologies are used in inappropriate ways or at inappropriate times. Have you encountered any of the following issues with your students?
a. Getting on Facebook during class?
b. Using Twitter to cheat on exams?
c. Cyber-bullying or mean-spirited comments?

11. In the coming school year, do you expect your use of social media to most likely:
a. Decrease
b. Increase
c. Remain the same 
12. If you currently DO NOT use social media in the classroom, how likely are you to start using it with the next 2 years?
a. Facebook
b. LinkedIN
c. Twitter

13. Does your Institution have a social media policy?

14. Please provide any additional comments or anecdotes about your impressions of the role of social media in higher education (optional). (Magna Publications, 2011, p. 4)

Questions 1 thru 12 helped answer research question number one, how are faculty using social media for teacher-student communication. Question 13 provided answers for Research question number 2, Are there privacy concerns faculty should be aware of because of the Federal Education Rights to Privacy Act (as will other questions developed based on answers from the first survey). Questions 5, 8, 10 and 11 helped answer research question number 3, what social media is being used by faculty to communicate with students.

At least two rounds of the surveys were conducted with a third and final round being an email chat with selected faculty members.

Round one survey questions determined if and how faculty at the selected community college were using social media, specifically Facebook, LinkedIn, and Twitter and were the faculty aware of FERPA issues. Round two went into further depth by asking more detailed questions based on the information gathered in the first round survey. The third round was based on the information gathered from the second round of surveys. This final round was an email chat conducted with a selected group of faculty members determined by their communication 
with students via social media. These faculty were then asked if they were aware of potential FERPA violations.

The recommended number of appropriate subjects for a reliable study varies according to researchers Delbecq, Van de Ven, and Gustafson (1975). They recommend the minimum number sufficient for a Delphi method survey to be relevant is 10-15. Hsu \& Sandford, (2007) determine, "if the sample size is too small, these subjects may not be considered as having provided a representative pooling of judgments regarding the target issue. If the sample size is too large, the drawbacks inherent within the Delphi technique such as potentially low response rates and the obligations of large blocks of time by the respondents and the researcher(s) can be the result" (p. 4). Keeping this information in mind, surveying over 200 plus faculty may take a little more time but the information should be more relevant given the number of faculty that one would anticipate to respond.

The researcher surveyed full-time faculty, and adjuncts. The outcomes from these surveys can help administration in higher education make better decisions regarding faculty use of social media and the use of social media policy. The research can help determine if there is a need for online social network policy.

\section{Data Collection}

A modified Delphi Method was used for data collection for this study. The Delphi method was developed at the Rand Corporation in the 1950's. It requires a group of "experts in their field" to respond to a survey where similar answers can be compiled to eventually work towards consensus in the project being discussed. After the first round, additional surveys are sent to participants. The information is collected and processed into the different areas of consensus thus eventually ending up with one (or only a few) solutions for the project (Rand Corporation (n.d.), Delphi Method.s study consensus is not the goal but commonalities of usage 
between community college faculty and social media and their awareness regarding FERPA and other confidentiality issues.

There are varying methods for conducting a Delphi with some researchers using three rounds of questions and others using more. The exact numbers of surveys are usually determined as the survey responses are evaluated, but the participants need to be aware there may be several surveys they will be asked to complete. It is also important that the right "experts" are chosen for the surveys. As the use of the modified Delphi has progressed over time the steps in the process have also been modified (Hsu, 2007, Rowe \& Wright, 1999, Hecht, 1977, Nelson, 2002, Hatcher \& Colton, 2002).

This researcher used the following steps based on information recommended by a previous study by A. Nelson, 2002:

1. Determined the experts to be surveyed (or the need to be researched)

2. Sent e-mail/letter explaining the importance of the research and asking for their consideration in completing the survey; explained there would be at least two more rounds of questions that would narrow down the information received; let them know they would receive a compilation of the information gathered; and their answers would be anonymous (Appendix C)

3. Developed the first round Delphi survey questionnaire (Appendix D)

4. Submitted the survey to participants

5. Evaluated responses from first round of survey

6. Prepared the second questionnaire based on information gathered from the first survey (Appendix E)

7. Submitted the second survey to participants 
8. Evaluated responses from the second round of surveys (repeated questions 6-8 until researcher determines information resources have been exhausted)

9. Prepared report to share conclusion of the results

Each round of surveys consisted of a series of Likert-type questions with an opportunity for open-ended comments by the participants (p. 6). The answers to the first round of questions were basis for the next round of questions. Faculty being requested to participate in the first round survey were sent an email introducing the questioner and explaining the reasoning behind the study; the importance of the study; the confidentiality of the survey; and a chance to win a \$25 gift card for participation. Participants were informed they may be asked to participate in potentially more survey rounds and an interview or a focus group at the end of the process.

\section{Guarantee of Anonymity and Confidentiality}

The anonymity of the participants in this study was explained in a letter accompanying the surveys. All of the data was kept safe on a secure, password protected, external data drive and on the researcher's personal computer. The researcher was the only person with access to the data and was the sole person responsible for processing the surveys, collecting the information and conducting the interviews. The participants in the interviews were reassured of the confidentiality and the anonymity of their information.

\section{Summary}

A modified Delphi Method was used in this study. The researcher sought to identify how faculty were using social media, by what method and were faculty aware of privacy issues that might pertain to the Family Educational Rights Privacy Act. The population used were faculty at a public mid-Atlantic Community College that offers certificates, Associate Degrees and Baccalaureate Degrees. The instrument used to collect the data was a replication of a survey conducted by Magna Publications, via Faculty Focus in the spring of 2011, to over 1000 faculty 
members in higher education (Magna Publications, 2012). An analysis of the findings will give insight into the privacy issues for faculty and administration in the use of social media to all stakeholders. 


\section{Chapter 4}

The data from this study is presented in this chapter. The chapter begins with the results of the first survey conducted, Exploring Social Media, and then results of the second survey, Exploring Social Media Two, and finally the email chat results. A modified Delphi Method was used for data collection for this study. The Delphi method was developed at the Rand Corporation in the 1950 's. It requires a group of "experts in their field" to respond to a survey where similar answers can be compiled to eventually work towards consensus in the project being discussed. After the first round additional surveys were sent to participants and the information was collected and processed into the different areas of consensus thus eventually ending up with one (or only a few) solutions for the project (Rand Corporation (n.d.), Delphi Method). For this study consensus was not the goal but commonalities of usage between community college faculty and social media and their awareness regarding FERPA.

\section{Faculty Characteristics}

The participants for this study were faculty from a mid-Atlantic Community College with a Carnegie Classification of Public, 4-year or above, Associate dominate with an enrollment profile of exclusively undergraduate four-year. The institution has an enrollment of approximately 3900 students (Carnegie Foundation, 2012). There are 97 full-time faculty and between 125 and 250 adjuncts, depending on the semester teaching at this institution .The institution offers certificates; associate degree programs; and is one of only thirty-four community colleges to be accredited to offer baccalaureate degrees (Russell, 2010, p. 7). The initial survey request was sent to all faculty with $44(\mathrm{~N}=97)$ percent being full time and 56 $(\mathrm{N}=123)$ percent being adjuncts. 


\section{Survey Number One - Exploring Social Media}

All faculty at the institution were given the opportunity to take the first survey regarding their use of social media. An anonymous survey request was sent to a population of 97 full-time and 123 part-time faculty at the chosen community college of which 53 faculty responded they were willing to complete the survey, for a $24 \%(\mathrm{~N}=53)$ rate of return. Survey One began with demographic questions and then was followed by 4 areas:

- Area 1 Faculty use of social media;

- Area 2 How long have faculty been using social media;

- Area 3 Faculty and student interaction on social media; and

- Area 4 Future use of social media by faculty.

Fifty-three faculty responded to the request to complete Survey One. As shown in Table One, the largest percentage of respondents were Instructors $(44 \%, \mathrm{~N}=23)$ with the next being full professors $(27 \%, \mathrm{~N}=14)$ and then Assistant Professor (15\%, N=7) and Associate Professors $(13 \%, \mathrm{~N}=8)$. Fifty-five percent $(\mathrm{N}=28)$ were term faculty with $27 \%,(\mathrm{~N}=14)$ tenured, $2 \%(\mathrm{~N}=1)$ tenure track and the remaining $16 \%(\mathrm{~N}=8)$ were instructional specialists. Sixty-nine $(\mathrm{N}=36)$ percent of the respondents were full time with $39 \%(\mathrm{~N}=16)$ adjuncts; $58 \%(\mathrm{~N}=30)$ were female; and $42 \%(\mathrm{~N}=22)$ were male. Seventy-three $(\mathrm{N}=38)$ percent of the respondents had worked for the institution more than five years with $17 \%(\mathrm{~N}=9)$ between 3 and 5 years, and $10 \%(\mathrm{~N}=5)$ between 1 and 2 years. None of the respondents had worked less than a year. 
Table 1

Faculty Demographics (Survey One)

\begin{tabular}{llll}
\hline Questions & Instructor & $\begin{array}{l}\text { Assistant } \\
\text { Professor }\end{array}$ & $\begin{array}{l}\text { Associate } \\
\text { Professor }\end{array}$
\end{tabular}$\quad$ Full Professor

Q1. What is your role in higher education?

\begin{tabular}{llll}
$\mathrm{N}=23(44 \%)$ & $\mathrm{N}=8(15 \%)$ & $\mathrm{N}=7(13 \%)$ & $\mathrm{N}=14(27 \%)$ \\
\hline$<$ 1 year & $1-2$ years & 3-5 years & $>$ 5 years
\end{tabular}

Q2. How many years have you worked in higher education?

$0 \% \quad \mathrm{~N}=5(10 \%) \quad \mathrm{N}=9(17 \%) \quad \mathrm{N}=38(73 \%)$

\begin{tabular}{lllll}
\hline & $\begin{array}{l}\text { Instructional } \\
\text { Specialist }\end{array}$ & Term & $\begin{array}{l}\text { Tenure } \\
\text { Track }\end{array}$ & Tenured \\
What is your designation? & $\mathrm{N}=8(16 \%)$ & $\mathrm{N}=28(55 \%)$ & $\mathrm{N}=1(2 \%)$ & $\mathrm{N}=14(27 \%)$
\end{tabular}

Fifty-eight $(\mathrm{N}=30)$ percent of faculty completing Survey One were female and $42 \%$ $(\mathrm{N}=22)$ were male. Sixty-nine $(\mathrm{N}=36)$ percent were full time faculty and $31 \%(\mathrm{~N}=16)$ were adjuncts. As shown in Table 2 below, Facebook was the most used social media site with thirtyeight $(\mathrm{N}=20)$ percent making daily postings. Six percent $(\mathrm{N}=3)$ checked Facebook at every opportunity, $15 \%(\mathrm{~N}=8)$ weekly and $8 \%(\mathrm{~N}=4)$ monthly. LinkedIn was the second most used social media site with twenty-five percent $(\mathrm{N}=13)$ of respondents posting monthly; $12 \%(\mathrm{~N}=6)$ posting weekly; $10 \%(\mathrm{~N}=5)$ posted daily; and as often as every opportunity $(2 \%, \mathrm{~N}=2)$. Respondents used Google Plus+ $(8 \% \mathrm{~N}=4)$ and Pinterest $(22 \%, \mathrm{~N}=11)$ at least every month and 12\% (N=6) used Google Plus+ daily while 8\%, $(\mathrm{N}=4)$ used Pinterest daily. DeviantArt, LiveJournal and Ask.fm were used by six percent $(\mathrm{N}=3)$ or less of the respondents. Faculty did not use MySpace, Tagged, Orkut, CafeMom, Ning, Meetup, or MyLife. 


\begin{tabular}{|c|c|c|c|c|c|c|}
\hline \multicolumn{7}{|c|}{$\begin{array}{l}\text { Table } 2 \\
\text { How Often Are Faculty Using Social Media (Survey One) }\end{array}$} \\
\hline \multicolumn{2}{|c|}{$\begin{array}{l}\text { How often do you } \\
\text { use the following } \\
\text { social media tools: }\end{array}$} & Never & Monthly & Weekly & Daily & $\begin{array}{l}\text { At Every } \\
\text { Opportunity }\end{array}$ \\
\hline Q6 & Facebook & $\mathrm{N}=17(33 \%)$ & $\mathrm{N}=4(8 \%)$ & $\mathrm{N}=8(15 \%)$ & $\mathrm{N}=20(38 \%)$ & $\mathrm{N}=3(6 \%)$ \\
\hline Q7 & Twitter & $\mathrm{N}=42(80 \%)$ & $\mathrm{N}=3(6 \%)$ & $\mathrm{N}=4(8 \%)$ & $\mathrm{N}=2(4 \%)$ & $\mathrm{N}=1(2 \%)$ \\
\hline Q8 & Moodle & $\mathrm{N}=47(90 \%)$ & $\mathrm{N}=1(2 \%)$ & $\mathrm{N}=3(6 \%)$ & $\mathrm{N}=1(2 \%)$ & $0 \%$ \\
\hline Q9 & LinkedIn & $\mathrm{N}=26(51 \%)$ & $\mathrm{N}=13(25 \%)$ & $\mathrm{N}=6(12 \%)$ & $\mathrm{N}=5(10 \%)$ & $\mathrm{N}=1(2 \%)$ \\
\hline Q10 & Pinterest & $\mathrm{N}=35(67 \%)$ & $\mathrm{N}=11(22 \%)$ & $\mathrm{N}=1(2 \%)$ & $\mathrm{N}=4(8 \%)$ & $0 \%$ \\
\hline Q11 & MySpace & $\mathrm{N}=52100 \%)$ & $0 \%$ & $0 \%$ & $0 \%$ & $0 \%$ \\
\hline Q12 & GooglePlus+ & $\mathrm{N}=34(65 \%)$ & $\mathrm{N}=4(8 \%)$ & $\mathrm{N}=8(15 \%)$ & $\mathrm{N}=6(12 \%)$ & $0 \%$ \\
\hline Q13 & DeviantArt? & $\mathrm{N}=51(98 \%)$ & $\mathrm{N}=1(2 \%)$ & $0 \%$ & $0 \%$ & $0 \%$ \\
\hline Q14 & Live-Journal & $\mathrm{N}=51(98 \%)$ & $0 \%$ & $\mathrm{~N}=1(2 \%)$ & $0 \%$ & $\%$ \\
\hline Q21 & Ask.fm & $\mathrm{N}=48(94 \%)$ & $\mathrm{N}=3(6 \%)$ & $0 \%$ & $0 \%$ & $0 \%$ \\
\hline
\end{tabular}

\section{How long have faculty been using social media}

As shown in Table 3, Facebook is the social media site respondents have been using the longest with $27 \%(\mathrm{~N}=14)$ using it longer than five years. Twitter and LinkedIn follow with 12 $13 \%(\mathrm{~N}=6-7)$ using them between three and five years. These are also the three social media sites used the most by faculty [One person did not respond to Twitter, one did not respond to Pinterest and four did not respond to MyLife] 


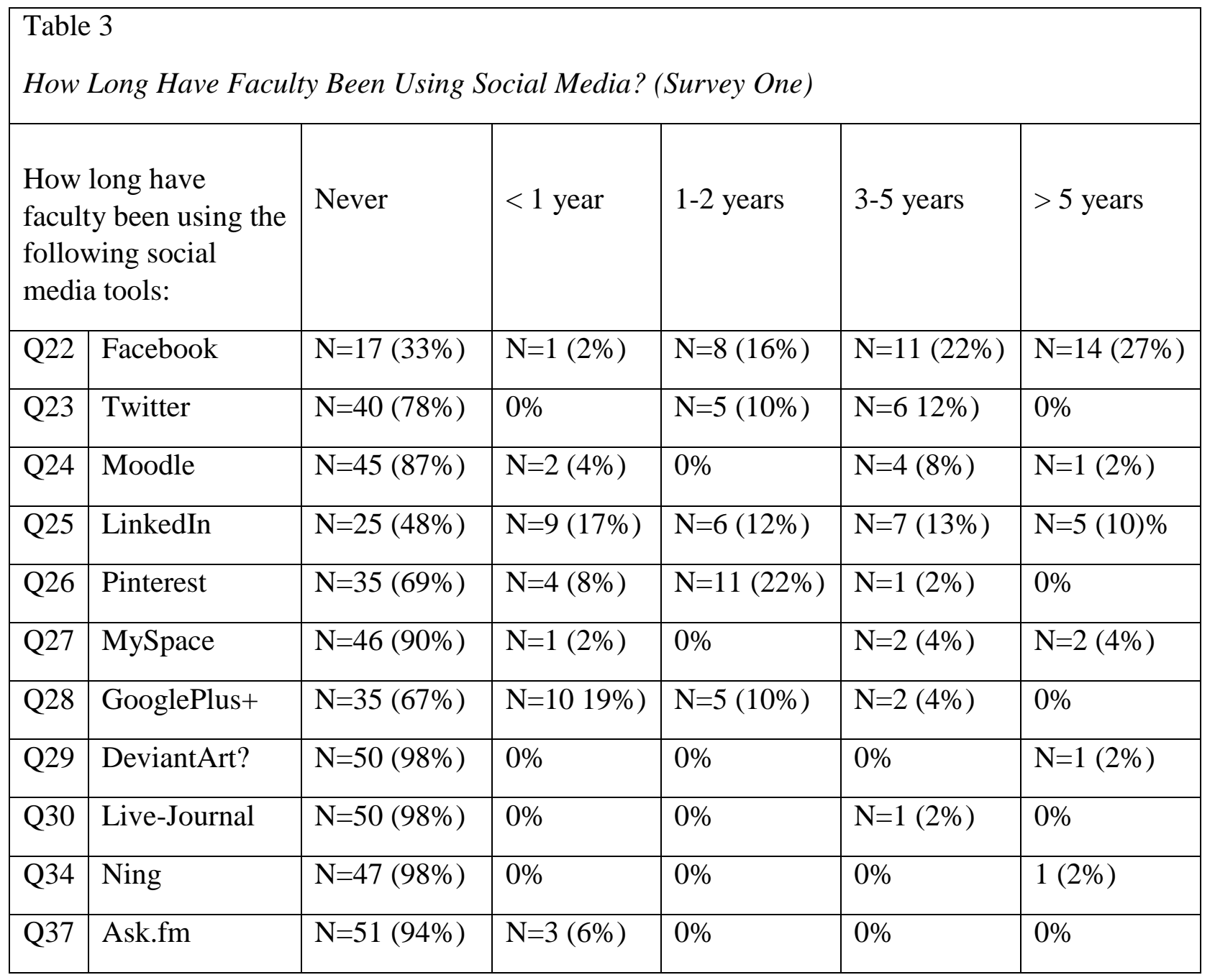

Table 4 shows the interaction between faculty and students using social media. Faculty were asked questions regarding their definition of personal and professional use of social media. Thirty-three percent $(\mathrm{N}=15)$ considered students professional contacts. Forty percent $(\mathrm{N}=20)$ had "friended" students on Facebook and sixty-three percent $(\mathrm{N}=32)$ checked they had spoken to students about their online reputations. When asked whether or not they had encountered any problems when using social media, fifty percent $(\mathrm{N}=17)$ checked they had not had any problems. Fifteen percent $(\mathrm{N}=5)$ of respondents reported they did not use social media. One responded they only used twitter and LinkedIn [as opposed to Facebook] and the others said they had heard of 
issues but they personally didn't have any problems themselves other than one respondent that quit using social media and that solved any problems.

Respondents with issues using social media $(34 \%, \mathrm{~N}=11)$ were concerned with student's addiction to social media, especially in the classroom. One respondent commented they only friend students who have graduated from their program and another stated they had their identity stolen through use of a social media site.

\section{Table 4}

Faculty and Student Interaction on Social Media (Survey One)

\begin{tabular}{|c|c|c|c|}
\hline & Questions & Personal & Professional \\
\hline Q38 & $\begin{array}{l}\text { When you think about how you use social media, do you } \\
\text { use these tools for Professional Use (such as students and } \\
\text { colleagues) or for Personal use during your free time? } \\
\text { (6 respondents did not answer this question) }\end{array}$ & $\mathrm{N}=31(67 \%)$ & $\mathrm{N}=15(33 \%)$ \\
\hline Q39 & $\begin{array}{l}\text { Have you ever "friended" a student on FACEBOOK? } \\
\text { (two respondents did not answer this question) }\end{array}$ & $\begin{array}{c}\text { YES } \\
\mathrm{N}=20(40 \%)\end{array}$ & $\begin{array}{c}\mathrm{NO} \\
\mathrm{N}=30(60 \%)\end{array}$ \\
\hline Q40 & $\begin{array}{l}\text { Have you talked to students about managing their online } \\
\text { reputations? (one respondent did not answer this question) }\end{array}$ & $\begin{array}{c}\text { YES } \\
\mathrm{N}=32(63 \%)\end{array}$ & $\begin{array}{c}\mathrm{NO} \\
\mathrm{N}=19(37 \%)\end{array}$ \\
\hline Q41 & $\begin{array}{l}\text { Despite the benefits of social media, problems can arise wh } \\
\text { in an inappropriate manner or at inappropriate times. Have } \\
\text { and if so what were they? The answers are divided in to thr } \\
\text { Comments regarding" Not" using social media, and concer }\end{array}$ & $\begin{array}{l}\text { ou the technolo } \\
\text { ou countere } \\
\text { s when using s }\end{array}$ & $\begin{array}{l}\text { sies are used } \\
\text { any issues } \\
\text { problems, } \\
\text { cial media. }\end{array}$ \\
\hline \multicolumn{2}{|c|}{ Did not have any problems: } & \multicolumn{2}{|l|}{$\mathrm{N}=17(50 \%)$} \\
\hline \multicolumn{2}{|c|}{ Comments regarding "not" using social media. } & \multicolumn{2}{|l|}{$\mathrm{N}=5(15 \%)$} \\
\hline \multicolumn{4}{|c|}{ I only use Twitter and Google. } \\
\hline \multicolumn{4}{|c|}{$\begin{array}{l}\text { I personally have not encountered any issues but I try to be cautious when using social } \\
\text { networking sites. }\end{array}$} \\
\hline
\end{tabular}


(Table 4 cont.)

I never friend a student until after they are out of my class. I do not make the request they do. Stopped using no problem

\begin{tabular}{l|l} 
Concerns regarding use of social media: & $\mathrm{N}=11(34 \%)$
\end{tabular}

Once a person stole my identity on Facebook and tried to raise money; I have had students put inappropriate pictures and comments on Facebook and I had to address these issues; of course, there are students that want to use social media during class time.

Yes, crossing boundaries of appropriate interactions.

Students accessing social media during lectures.

I've quit teaching in computer labs as students get distracted by the availability of social media.

Yes, have seen bullying attempts and inappropriate political ads.

Texting can be a distraction.

Political commentary during last election was heated, but I rarely have issues.

I've mentioned "the issue" to the individual and talked about how others may perceive the post.

Students distracted in class by using social media.

I only "friend" students on FB after they have graduated from the program. Our division has a social media policy prohibiting certain student behavior and indicates disciplinary actions that can occur if the policy is violated. I have grading rubrics that establish how students should partake in discussion threads.

Most notably, my students (particularly younger students) are somewhat incapable of going an entire class period (one hour or so) without checking their Facebook pages. When I teach I in computer labs, I sometimes spend the first 5 or 10 minutes of class telling the students to turn off their social media sites. Some students react as though they are physically addicted to social media. Their hands slowly creep toward their keyboards and I have to tell the same people over and over again to stop playing on Facebook. I never befriend students online because I can't censor what people post to your page and I don't want the students to feel like they can get a good grade just by being my friend. 


\section{Future use of social media by faculty}

Faculty were asked in the first survey if they planned on using social media with students in the future. Most responded they would not use social media with students in the next two years category or only if I have too. The numbers range from $37 \%,(\mathrm{~N}=19)$ to $76 \%,(\mathrm{~N}=37)$ that they will not be using social media in the next two years. The next highest group was "only if I have too" with percentages ranging from $14 \%,(\mathrm{~N}=7)$ to $24 \%,(\mathrm{~N}=12)$. There were some undecided between $6 \%,(\mathrm{~N}=3)$ and $27 \%,(\mathrm{~N}=13)$ but only a few respondents that said they probably will use it - those sites were Facebook ( $2 \%, \mathrm{~N}=1)$, Twitter (6\%, $\mathrm{N}=3)$, Moodle (4\%, $\mathrm{N}=2)$, Pinterest $(2 \%, \mathrm{~N}=1)$, GooglePlus+ $(19 \%, \mathrm{~N}=10)$ had the highest interest, and Live-Journal $(2 \%, \mathrm{~N}=1)$. Five sites will definitely be used and those were Twitter, Moodle, LinkedIn, Pinterest and GooglePlus+. Fifteen percent $(\mathrm{N}=8)$ did not respond regarding Facebook, 2\% (N=1) did not respond regarding Twitter, LinkedIn, Pinterest, GooglePlus+, DeviantArt, MeetUp, MyLife, 4\% $(\mathrm{N}=2)$ did not respond regarding Ask.fm, and 6\% (N=3) did not respond regarding Orkut, or NIng.

Twenty-five percent $(\mathrm{N}=13)$ of faculty responded that the college had a social media policy and $4 \%(\mathrm{~N}=2)$ thought there was not any social media policy while their use of social media would remain the same, $6 \%(\mathrm{~N}=3)$ actually thought its use would decrease, $15 \%(\mathrm{~N}=8)$ responded it would increase slightly and 6\% ( $\mathrm{N}=3$ ) responded it would increase significantly. 


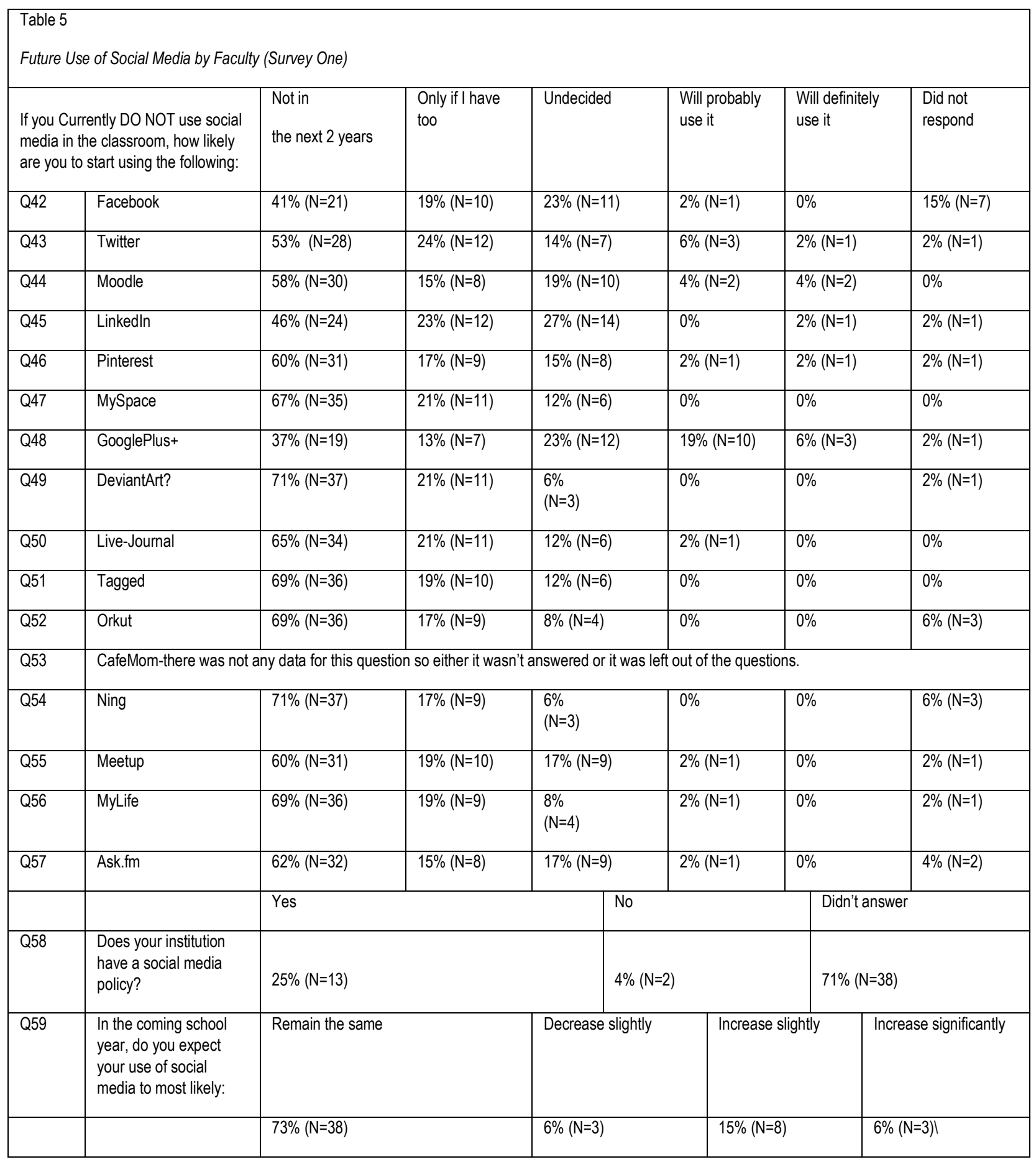

The last survey question, number 60 , asked for comments or anecdotes regarding the use of social media. Table six contains those comments and antidotes regarding their impressions of the role of social media in higher education. The comments are divided in to three areas: Faculty 
that use social media with students; faculty that dislike using social media with students; and faculty who are undecided about the use of social media with students. There were 25 responses total, with $64 \%(\mathrm{~N}=16)$ making positive comments regarding faculty use of social media with their students. The consensus was educators will have to embrace social media to reach all learners. They use Facebook to work on projects with students, to post class information where students have easy access to the information. While some faculty use Facebook for student organizations they do not use it in the classroom. One respondent commented that social media is being used by employers to contact employees so students need to know how to use it to be competitive. A couple respondents reported they did not send friend requests to students but they would accept them as friends if they ask.

Twenty percent $(\mathrm{N}=5)$ of the respondents did not like the use of social media with students. One faculty responded it was frivolous and trivial while others thought it encouraged students to continuously check for messages and promote their addictive behaviors while another thought we need to teach that there are other means of research and that everything cannot be found in social media.

The remaining $16 \%(\mathrm{~N}=7)$ percent didn't know much about social media and again referred to the addictive effects it had on students. One respondent stated they used a Mathlab and they had a webpage on Google sites but they didn't use social media. 


\begin{abstract}
Table 6
Additional Comments Made by Faculty for Social Media (Survey One)

Faculty that use social media with students (statements are written as they were in the survey):

I believe that as educators of learners in the $21^{\text {st }}$ century we will have to embrace social media to reach all learners.

I use Facebook for students working on projects or in some classes where we need to keep in contact but don't necessarily need an entire course management system. It works very well. Students have easy access and get their messages quickly.

Social media provides an excellent opportunity to "get to know" online students in a more informal way. I use it to push content from WSJ, HBJ, and other business journals for students to read. For the marketing classes, it is required that students create a FB page for a local business or organization.

Employers are using them and students need to have profiles with several of them (such as Linkedln) to connect with potential employers.

I think it is a useful tool, given proper training for students and faculty.

I use a facebook group for my labs and post on assignments on google+, sometimes former students friend my on facebook which I usually accept. I once had a student calling in sick who posted vacation pictures openly on facebook, which another student told me.

I keep a Facebook page for a student organization that I advise and posts events on it, but I don't use it in the classroom.

It's a key to the future. Give me six months to research (on Twitter) the most effective ways to use it in the classroom, and get administrative "APPROVAL", and I would run with it (and be happy to share the info). Some years ago (maybe 5), I opened up a MYSPACE Page for a class. I intended to use it as a bulletin board for assignments/deadlines. This was when a majority of students used MYSPACE. I knew that they were on MYSPACE a couple of times a day, but were not checking their WVUP email on any regular basis. The administration called the chair of my department and had a totally incorrect idea of what I was trying to do. (this was before the social media policy was created). At the last Adjunct conference Adjuncts were complaining that they had no way to get in contact with each other. I had just presented a class on how to do research on Twitter, so I created a hashtag for WVUPadj. I was congratulated by those in power, and it was announced at the luncheon. (Sat.). Monday the same person called me into her office to tell me I had violated the social media policy, and I needed to delete the hashtag. I explained that I did not think you could "delete" a hashtag. The institution does not encourage the use of social media, and many of the faculty members are not very tech savy, or interested in redesigning their curriculum. When the next generation is running things we will see a quantum leap in the use of social media in the classroom. Great topic for a dissertation.
\end{abstract}

I have tried to inspire blogs on MOODLE but students do not participate. Almost everyone texts and it is easier. Students like nature, follow the path of least resistance.

I'm a fan of technology, but prefer to only use media attached to the school server, such as google+ which is clearly available to us all.

Regarding the question "Have you ever "friended" a student on FACEBOOK?" I have never sought to add a student as a friend, but I have been added by students.

I find it useful to see what the student climate is.

I use OpenClass [schools LMS system] and have posted on the timeline there; but I have students who don't use the information or who never access it.

I do not "friend" students; however I do accept friend requests.

Social media can be used to enhance learning and to reach different styles of learning.

Posting common information, such as take-home quizzes and syllabi, on facebook provides students with access to those materials without worrying about keeping a hard copy. It also saves paper.

\title{
Faculty who dislike the use of social media with students:
}

I really don't like using social media in the classroom; I feel it provides an excuse for students to browse facebook and others during classtime and at other times when the really need to be focusing on other matters.

My outsider's view is that the "addictive" of social media diminishes the development of listening, analyzing, and critical thinking skills.

At this time, I feel that social media has the (deserved) reputation as being silly and trivial. It is very asual in its use and implies a casual relationship between users. As a professor, my relationship with students is not and should not be that casual.

I do not believe it belongs in the classroom because of risk of violations of confidentiality. 
(Table 6 cont.)

\begin{tabular}{l}
$\begin{array}{l}\text { I know many people use Facebook in the classroom because the students already use it and are comfortable with it, but students need to be pushed to } \\
\text { learn/find information that may not be available in the realm of social media. I don't feel the need to cave to my students' every desire. I don't feel we're } \\
\text { helping prepare them for the professional world by telling them that since they're all addicted to Facebook anyway, we're going to go ahead and just make } \\
\text { that our primary teaching tool. They need to be able to sit in meetings or at desks at work and actually pay attention to people/issues that exist in the real } \\
\text { world. }\end{array}$ \\
\hline Faculty who are undecided about the use of social media with students: \\
\hline I am aware that many faculty use social media for professional purposes, and I assume that more faculty will do so in the future. \\
\hline Don't even know what most of these are. No idea how they could be used in an academic setting if they are SOCIAL media. \\
\hline Social media have their place, but too many people get addicted to them. \\
\hline $\begin{array}{l}\text { I use technology like MyMathLab extensively and I have a website under Google sites I use to provide students access to copies of my syllabus and } \\
\text { instructional videos. But I do not use social media. }\end{array}$
\end{tabular}

After reviewing the first survey, any response answered with a zero response, such as, "I do not use this type of social media," was discarded for the second survey. Responses that referred to using social media were repeated in the second survey. All of the social media sites listed in survey one that were listed as $94-100 \%$ never used them were discarded from the second survey. Those social media sites were LiveJournal, Tagged, Orkut, DeviantArt, CafeMom, Ning, MeetUP, MyLife, and Ask.fm. 


\section{Survey Two - Use of Social Media 2}

Participants for Survey Two were chosen based on their responding to Survey One and including their email. There were several surveys submitted in round one that did not have any responses so for Survey Two, the researcher sent surveys to those with an email from the first survey. It was not clear from the first survey which specific respondents used social media with their students so these questions were repeated in the second survey. The second survey was sent to a population of 44 faculty. These faculty included their name in the first survey and were identified by email address only. Twenty-nine $(\mathrm{N}=29)$ of the 44 responded, resulting in a return rate of $66 \%$. The second round survey began with similar demographic questions to survey one and was then followed by four areas:

- Area 1 - Faculty use of social media (same topic as in Survey One)

- Area 2 - Clarifications regarding social media (there appeared to be misconceptions regarding social media in survey one. One comment talked about hosting a website in Google but it wasn't considered social media and other responded they didn't know how it could be used in an academic setting when it was SOCIAL media)

- Area 3 - Faculty and students interaction on social media (same topic as Survey One)

- Area 4 - Policy and FERPA and social media

Table 7 covers the demographics for Survey Two. There were only a few percentage points different in the role of faculty between the two surveys. Thirty-eight $(\mathrm{N}=12)$ percent of faculty in Survey Two were Instructors compared to 44\% ( N=23) in Survey One; 22\% $(\mathrm{N}=7)$ were Assistant Professors in Survey Two and 13\% (N=7) in Survey One; 13\% (N=4) were Associate Professors in Survey Two and 15\% (N=8)in Survey One; 22\% (N=7) were 
full professors in Survey Two and 27\% (N=14)in Survey One. The comparison between designations was also very close. Term faculty in Survey Two were 59\% (N=19) and Survey One were 55\% (N=28); Instructional Specialist in Survey Two were 13\% $(\mathrm{N}=4)$ and 16\% $(\mathrm{N}=8)$ in Survey One; $28 \%(\mathrm{~N}=9)$ were tenured in Survey Two and 27\% $(\mathrm{N}=14)$ in Survey One. There weren't any faculty on a tenure track in Survey Two and 2\% $(\mathrm{N}=1)$ in Survey One. Females outnumbered males as previously with 66\% (N=21) in Survey Two and 58\% $(\mathrm{N}=30)$ in Survey One; and males 34\% $(\mathrm{N}=11)$ in Survey Two and 42\% $(\mathrm{N}=22)$ in Survey One; $69 \%(\mathrm{~N}=36)$ were full time and $31 \%(\mathrm{~N}=16)$ adjuncts in Survey Two and $77 \%(\mathrm{~N}=24)$ full time and 23\% (N=7) adjuncts in Survey One. In Survey One, 73\% (N=38) responded they had been working in higher education greater than five years and in Survey Two, 75\% $(\mathrm{N}=24)$ responded they have worked in higher education greater than five years. 


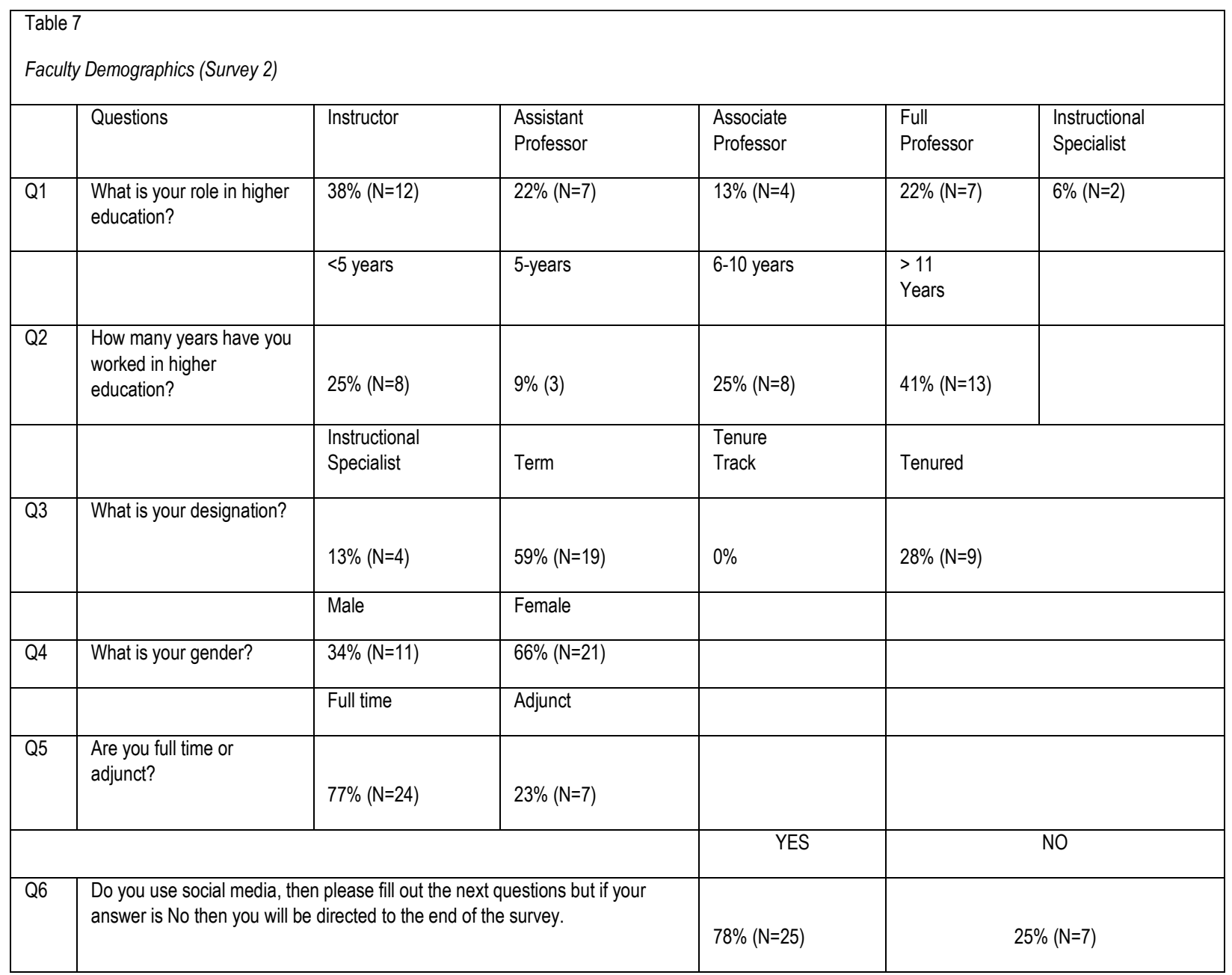

\section{Use of social media}

In Survey One the question was asked how many years faculty had been using social media but in Survey Two, in trying to drill down through the information, the question was ask, how many hours per week do faculty use social media. The lack of use for social media that received a $94 \%$ or higher in Survey One were deleted from Survey Two. Respondents spent most of their time using the social media site Facebook with 18 hours per week, GooglePlus+ at 10 hours, Twitter and Pinterest at nine hours and Moodle and LinkeIn were last with six and two hours respectively. These statistics are shown below in Table 8. 
Faculty were asked if they were aware when they posted to their Facebook page, if a friend "liked" it then all of their friends-friends could see it. K. Knibbs (2014), wrote, "The first thing you have to realize about Facebook is Nothing you put there is truly private" (Introduction, para 1). Ninety percent $(\mathrm{N}=19)$ were aware their information would be shared with only $10 \%$ $(\mathrm{N}=2)$ not aware.

Upon review of Survey One, it was apparent that some respondents were not sure about the use of social media, so in Survey Two questions regarding professional and personal use of social media were asked again and elicited more detail. Faculty were asked for their specific definition of professional use on social media as listed in Q9 in Table 8. The respondents still gave somewhat conflicting answers as one comment was "any social media in any form that allows a faculty member to fulfill his/her job duties, and another responded with "I do not think people are using social media for professional purposes," while yet another stated, "Teachers of higher education need to be cautious of the potential issues that can present by "being friends" with students."

Faculty were given five options and asked if they considered any of them to be professional entities and 18 of the respondents still considered friends and family as professional contacts. Sixty-four percent $(\mathrm{N}=14)$ considered business acquaintances and students to be professional contacts and $86 \%(\mathrm{~N}=19)$ considered their teaching colleagues professional $(9 \%$, $\mathrm{N}=2$ responded other but did not identify). All respondents $(100 \%, 21)$ considered family to be personal contacts while 5\% ( $\mathrm{N}=1)$ considered business acquaintances and students as personal contacts $(10 \%, \mathrm{~N}=2)$ responded other but did not identify). 


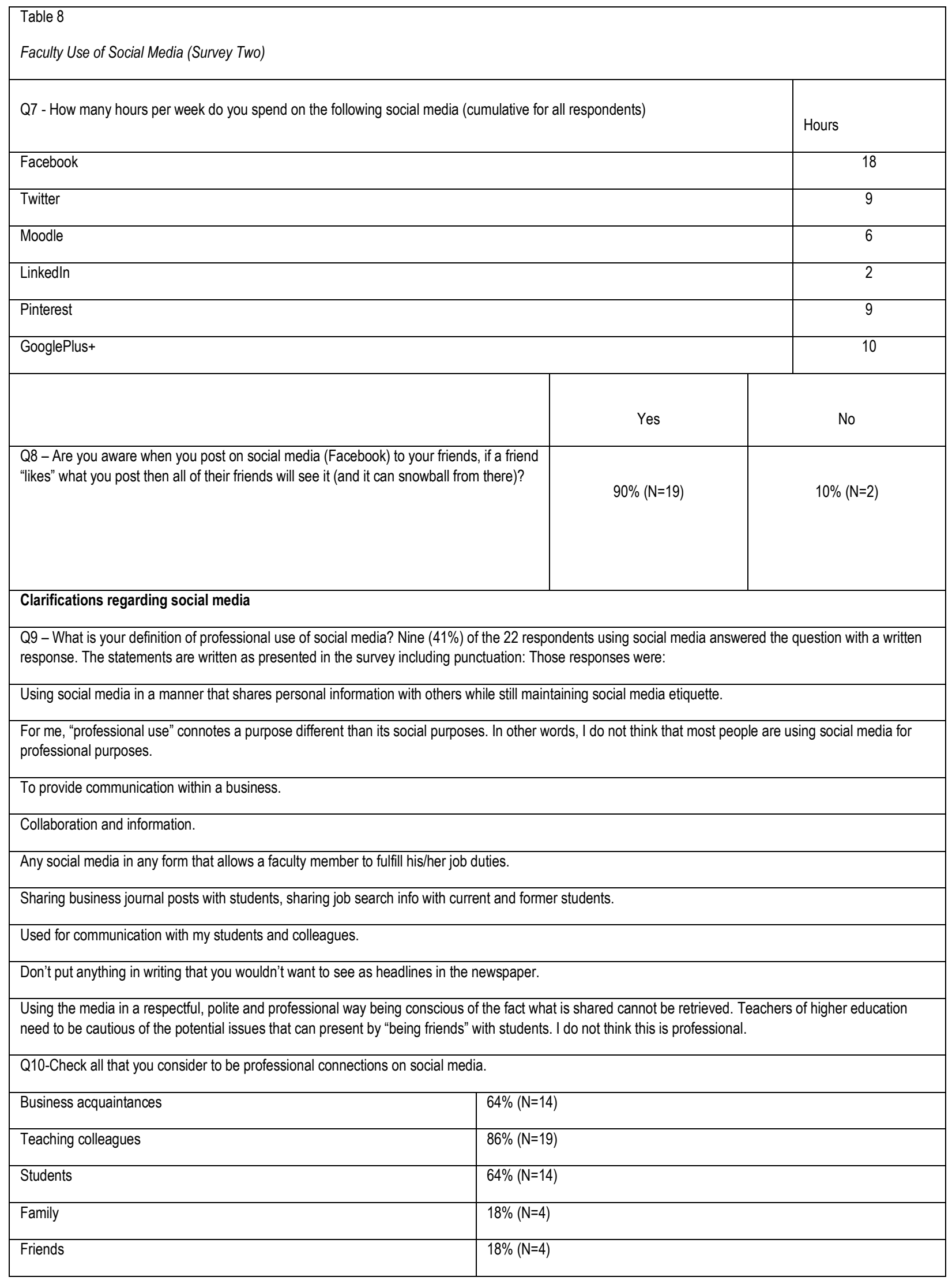


(Table 8 Cont.)

\begin{tabular}{|l|l|}
\hline Other - unidentified & $9 \%(\mathrm{~N}=2)$ \\
\hline Q11-Check all that you consider personal communications only. (1 did not respond) \\
\hline Business acquaintances & $5 \%(\mathrm{~N}=1)$ \\
\hline Teaching colleagues & $0 \%$ \\
\hline Students & $5 \%(\mathrm{~N}=1)$ \\
\hline Family and friends & $100 \%(\mathrm{~N}=21)$ \\
\hline Other unidentified & $10 \%(\mathrm{~N}=2)$ \\
\hline
\end{tabular}

\section{Faculty and students using social media}

Questions about faculty using social media with students were included in both Survey One and Survey Two. Forty-seven $(\mathrm{N}=9)$ percent of the respondents in Survey Two have friended students on social media, while $40 \%(\mathrm{~N}=20)$ of respondents in Survey One have friended students.

Questions exclusive to Survey Two show 5\% $(\mathrm{N}=1)$ of respondents have initiated friending a student, and $21 \%(\mathrm{~N}=4)$ have friended students that asked them first. Forty-one $(\mathrm{N}=8)$ percent responded they never friend current students and $16 \%(\mathrm{~N}=3)$ replied they had "defriended" students that were in their classes currently. Respondents had friends who were students on Facebook $(69 \%, \mathrm{~N}=11)$, GooglePlus+ $(25 \%, \mathrm{~N}=6)$ and LinkedIn $(6 \%, \mathrm{~N}=1)$. Ten $(\mathrm{N}=2)$ percent of respondents reported they had posted something on social media that they later regretted.

There were three specific questions pertaining to questions students might potentially ask faculty and they were [only three faculty responded to these questions]:

- $\quad$ Can you tell me what my grades are $(33 \%, \mathrm{~N}=1)$ ?

- Can you help me with this class $(100 \%, \mathrm{~N}=3)$ ? 
- Can you advise me regarding a situation at this school $(33 \%, \mathrm{~N}=1)$ ?

Respondents $(14 \%, \mathrm{~N}=3)$ in Survey Two reported they knew there was a social media policy while $27 \%(\mathrm{~N}=6)$ knew there was not a policy and $59 \%(13)$ were not aware if there was a social media policy or not at this institution. For the same question in Survey One $25 \%(\mathrm{~N}=13)$ said yes they were aware of a policy, $4 \%(\mathrm{~N}=2)$ reported there wasn't a social media policy and $71 \%(\mathrm{~N}=37)$ did not answer the question.

\section{Policy, FERPA and social media}

The last two questions in Survey Two refer to the Federal Educational Rights of Privacy Act (FERPA). This question was not asked in Survey One as it was important to establish that faculty use social media with their students in order for FERPA to be relevant. Table 10 displays that $73 \%$ respondents (22) are aware of FERPA while $27 \%$ are not aware of FERPA. The last question asked for antidotes or other information that faculty deemed helpful regarding faculty use of social media with students. Seven faculty participated in this portion of the survey, two of their statements referred to buttons on the survey so they were discarded from this report. Of the 


\begin{tabular}{|c|c|c|}
\hline \multicolumn{3}{|l|}{$\begin{array}{l}\text { Table } 9 \\
\text { Faculty and Students Using Social Media (Survey Two) }\end{array}$} \\
\hline \multicolumn{3}{|c|}{ Q12 - Check all that apply regarding friending students on social media (19 of the 22 respondents using social media answered the question). } \\
\hline \multicolumn{2}{|l|}{ I have friends that are students on social media. } & $47 \%(\mathrm{~N}=9)$ \\
\hline \multicolumn{2}{|l|}{ I have current students that are friends on social media. } & $37 \%(\mathrm{~N}=7)$ \\
\hline \multicolumn{2}{|l|}{ I have initiated friending my students on social media } & $5 \%(\mathrm{~N}=1)$ \\
\hline \multicolumn{2}{|l|}{ I have friended students that have asked me to friend them first. } & $21 \%(N=4)$ \\
\hline \multicolumn{2}{|l|}{ I have never friended a current student on social media. } & $41 \%(8)$ \\
\hline \multicolumn{2}{|l|}{ I have "defriended" students that became "current" students on social media. } & $16 \%(3)$ \\
\hline \multicolumn{3}{|c|}{ Q13-If you currently have students that are friends on social media, check all of the social media that applies (16 faculty responded to this question) } \\
\hline \multicolumn{2}{|l|}{ Facebook } & $69 \%(11)$ \\
\hline \multicolumn{2}{|l|}{ Linkedln } & $6 \%(1)$ \\
\hline \multicolumn{2}{|l|}{ Twitter } & $0 \%$ \\
\hline \multicolumn{2}{|l|}{ Moodle } & $0 \%$ \\
\hline \multicolumn{2}{|l|}{ Pinterest } & $0 \%$ \\
\hline \multicolumn{2}{|l|}{ Google Plus+ } & $25 \%(N=4)$ \\
\hline \multicolumn{3}{|c|}{$\begin{array}{l}\text { Q14- Have you ever answered questions or posted things on social media in response to the following questions (check all that apply)?[3 faculty responded } \\
\text { to the questions] }\end{array}$} \\
\hline \multicolumn{3}{|c|}{\begin{tabular}{|l|l|} 
Can you tell me what my grades are? & $33 \%(\mathrm{~N}=1)$
\end{tabular}} \\
\hline Can you help me with this class? & \multicolumn{2}{|l|}{$100 \%(N=3)$} \\
\hline Can you advise me regarding a situation related to school? & \multicolumn{2}{|l|}{$33 \%(N=1)$} \\
\hline $\begin{array}{l}\text { Q-15-Have you ever posted something on social media that you regretted posting later? ( } 21 \text { faculty } \\
\text { responded to this question) }\end{array}$ & Yes $10 \%(N=2)$ & No $90 \%(N=19)$ \\
\hline \multirow[t]{2}{*}{ Q16- Do you know what the social media policy is at this college? [22 faculty responded] } & Yes $14 \%(N=3)$ & No $27 \%(N=6)$ \\
\hline & \multicolumn{2}{|c|}{$\begin{array}{l}59 \%(\mathrm{~N}=11) \text { did not know whether there was a policy } \\
\text { or not }\end{array}$} \\
\hline
\end{tabular}

five statements, two of them discuss an issue in the same department where the department does have a social media policy with one of the issues referencing faculty and the other the student, but both could potentially have been a FERPA violation. Another responded they didn't really recognize a difference between current and former students and they used GooglePlus+ and LinkedIn and “these didn't have friends" so it wasn't an issue; however GooglePlus+ has 
"circles" [followers or friends] and LinkedIn has "connections." Of the two remaining

comments, one uses social media only as an observer and the other connects with students via email only.

\begin{tabular}{|l|l|}
\hline \multicolumn{2}{|l|}{ Table 10} \\
Policy, FERPA, and Social Media (Survey Two) \\
\hline $\begin{array}{l}\text { Q17- Are you aware of the Family Educational Rights of Privacy Act (FERPA) and how this act might } \\
\text { affect communication between students and faculty when using social media [22 faculty responded] }\end{array}$
\end{tabular}

\section{Interviews (email chat)}

Criteria for faculty chosen for the final interviews (email chat) was based on who answered yes to any of at least two of the following questions in Survey Two:

- I have friends who are students on social media

- I have current students who are friends on social media

- I initiate friending my students

- I accept friend requests from students who ask me to friend them first on social media 
All five (N=5) eligible faculty agreeing to participate in the interview process completed the interviews for a $100 \% \%$ participation rate.

Interview questions were determined based on the results from the second round survey as the researcher wanted to further verify faculty use of social media with students and whether or not they were aware of the potential for FERPA violations. Demographic questions were not repeated as all participants were faculty at the chosen institution who participate in the use of social media. Four respondents were full time faculty and one was an adjunct.

\begin{tabular}{|c|c|}
\hline & w Questions for Interviews \\
\hline Q1 & $\begin{array}{l}\text { At what point do you determine it is acceptable for professors and students to be friends on social media? } \\
\text { a. Whenever they ask } \\
\text { b. When they are no longer your students } \\
\text { c. Other (list) }\end{array}$ \\
\hline Q2 & $\begin{array}{l}\text { Who should initiate the friending? } \\
\text { a. The student } \\
\text { b. The faculty }\end{array}$ \\
\hline Q3 & $\begin{array}{l}\text { Have you experienced awkward interactions between professor and student friends? } \\
\text { a. Yes (in what way) } \\
\text { b. No }\end{array}$ \\
\hline Q4 & $\begin{array}{l}\text { Do you use social media (Facebook, i.e.) in class? } \\
\text { a. Yes (please explain) } \\
\text { b. No }\end{array}$ \\
\hline Q5 & $\begin{array}{l}\text { Faculty sometimes ask students to create blogs on social media. It is not considered an educational record because the school doesn't maintain the } \\
\text { record. Can you describe how this could potentially be a violation of FERPA? }\end{array}$ \\
\hline Q6 & When you are talking to your "students" via social media do you ever discuss grades, course enrollments, or class schedules (list all that apply). \\
\hline Q7 & $\begin{array}{l}\text { Have you ever, or are you aware of a faculty member revealing personal data about a student, or openly correcting them, or making them feel } \\
\text { awkward on a social platform? If yes, can you share your example? }\end{array}$ \\
\hline Q8 & $\begin{array}{l}\text { Check/highlight all of the following that you consider a violation of FERPA. } \\
\text { a. Sharing students grades where someone other than the student can view them } \\
\text { b. Criticizing the student publically } \\
\text { c. Discussing a student's grades with a faculty member via email } \\
\text { d. Revealing any information that can identify the student } \\
\text { e. Revealing courses that the student is currently taking }\end{array}$ \\
\hline Q9 & Please share any suggestions or concerns you might have regarding faculty and students sharing together via social media. \\
\hline
\end{tabular}


These interviews were conducted using an email format where participants answered the questions and then further questions could be discussed if necessary. The questions were multiple choice with a request to explain the respondent's answers.

Faculty interviewed were asked at what point they determined it acceptable for professors and students to be friends on social media. Two of the interviewees no longer were friends with students on social media. The remaining three respondents have current students as friends on social media. Respondent F2, (March 6, 2014), states "I use Google Circles and Facebook Groups to stay in contact with my students, monitor their group work, post assignments, discussions, and announcements. In order to do this, I must 'friend' them."

Another respondent explained why it was easier to keep them as friends than to delete them:

At one point, I accepted requests only from people no longer in my classes-but then they sometimes enrolled again. I am inclined now to accept most student requests (using individual judgment -for students in introductory courses. I tend to wait until they are no longer my students). But block students from receiving some of my posts (F3, March 6, 2014).

The last respondent uses Facebook for teaching purposes and their comments were:

I choose other because I have several students and classes that use Facebook groups to communicate, especially in courses where I find it easier to use Facebook groups than to have students pay extra fees for the CMS provided by the 
college. I often befriend students on Facebook so that our classes can operate with these groups (F1, March 6, 2014).

When asked, four of the five interviewees responded the student should do the friending with remaining respondent stating the faculty should be the one to initiate the friending.

Four respondents have not experienced awkward interactions with their students although one of them commented,

“No, I wouldn't say awkward interactions, but I have seen behavior by my students on Facebook that I don't think is best for their futures. I do mention these issues with them and remind them of the very public profile they are creating of themselves and how that will impact future endeavors." (F1, March 6, 2014)

The faculty member responding with a "yes" regarding awkward interactions wrote, "Students have a tendency to let the judgments fly when they are angry about some school policy. What I have been able to do in some of these situations is send the student to the appropriate office to handle the concern." (F3)

Two respondents do not use social media (Facebook, i.e.) in class? The remaining three respondents made these comments:

Yes, as noted before we frequently use Facebook groups in journalism courses. These groups are closed and are a place for brainstorming and sharing information. For example, my video production class puts all of their script ideas into a Facebook group. In my public relations courses, we plan our campaigns and keep up to date on the status of all participants through Facebook group postings. 
I also frequently use Google groups with classes now, and Google is very emergent in the social media right now. (F1)

By “in" class, do you mean in a FTF class? If so, I use FB postings from my friends that include articles, videos, etc. that are pertinent to the material being covered. FB supports collegiality for me and my former 'teacher' friends. I also show the videos, etc. in class as a stimulus for discussion and to illustrate concepts. Occasionally, I share this material through the Google groups and FB groups as FYI information. (F2.

And finally, "I use Twitter to let students know the questions that will be on our chapter quizzes. I have an assignment where students compare two theorists and some use Facebook and some use Twitter to do this (F5).

Faculty sometimes ask students to create blogs on social media. It is not considered an educational record because the school doesn't maintain the record. Faculty were asked to describe how this could potentially be a violation of FERPA. Two interviewees did not see it as an issue. The other interviewees suggested that students need to know upfront that something outside of their Course Management System is considered public property. If students willingly post information, then it shouldn't be a violation, but early admissions students (high school students who cannot legally give permission) could be an issue, and finally one said students sharing information about other students should not be shared without written permission.

The interviewees were asked when talking with their students via social media, if they ever discussed grades, course enrollments, or class schedules and to list all that apply. Two 
respondents said no, they did not discuss these items with students. Interviewee F1 (March 6, 2014) wrote:

I have used Google groups and Facebook groups to list all course assignments. Personal messages included grades, but those were never made public. Again, these were closed groups and only members could see the conversations. Class schedules are definitely part of the use.

Interviewee F2, (March 6, 2014) commented:

I rarely "talk" to students on social media except to share course information. I have never discussed grades, course enrollments, or class schedules. If I had to communicate with a student about his/her grade, it would be through a private message.

And respondent F3, (March 6, 2014) added:

My first response is "no," but I realize that I have from time to time emailed the entire classes without hiding the recipient list. Generally, what I send is a revision of the course schedule or an updated assignment.

Faculty were asked if they had ever, or are you aware of, a faculty member revealing personal data about a student, or openly correcting them, or making them feel awkward on a social platform? If yes, would they share their example? Three responded they were not aware of any situation or they did not do this themselves. One of the remaining faculty stated they were not aware of faculty but they have known of incidents where the "institution" seemingly argued or were rude to students when they asked questions or made comments on Facebook and Twitter. The other interviewee wrote: 
My online classes use discussion forums; students are required to post things like thesis statements of essays for comments/suggestions by class member. If the post requires major correction, I generally PM [private message] the students, but on at least one occasion, I hit "send" in the discussion forum rather than opening the email section of OpenClass. The student was fine, but the moment was potentially awkward (F3, March 6, 2014).

The interviewer asked the five faculty to check/highlight all of the following they considered a violation of FERPA.

a. Sharing students grades where someone other than the student can view them

b. Criticizing the student publically

c. Discussing a student's grades with a faculty member via email

d. Revealing any information that can identify the student

e. Revealing courses that the student is currently taking

Faculty were not sure about this question. One responded they did not think any of these would be a violation while another thought they all were potential violations of FERPA. Another thought it would depend on the situation because "Early Alerts" for example, must have identifying information in order for someone to take action to help the student or what if it were face to face. One faculty member picked criticizing the student publicly and made the following comment,

In grad school, I can remember professors being negative when students gave particularly lame class presentations. These moments were embarrassing. But 
given that the entire class had just witnessed a substandard performance by someone who should have known better, are such things a violation of FERPA? I don't know (F3, March 6, 2014).

At the end of the interview questions participants were asked to please share any suggestions or concerns they might have regarding faculty and students sharing together via social media. Interviewee F1, stated using common sense, respecting the rights and privacy of others, and making mature, rational decisions always seemed to be good guidelines to follow. Participant F3 isn't particularly worried about her cat pictures and wrote she thinks" it a good thing when we see each other as fellow human beings. We do, however, need to be careful about what we share."

Interviewee F2, (March 6, 2014) wrote:

Institutions must have a clearly defined policy regarding the use of social media. This policy must be communicated to staff, faculty, and students. Clear consequences for violations of the policy should be in place as well as an understanding of who will monitor social media pages connected to the institution. Communication on social media falls under the same policies as does FTF communication regarding privacy, harassment, etc. Because social media has become embedded in our daily communication and it is viewed in such a casual way, there must be a clear delineation in the minds of students, faculty, and staff between personal and institutional communication and where the two overlap.

Interviewee F4 stated: Faculty frequently utilize weblogs to interact with students. I try to maintain a perspective of neutrality when it comes to social media. In 
other words, I do not use social media as a platform for discussing classes, or course related concerns, or other political issues (March 6, 2014).

And finally interviewee F5 commented: It is difficult know where to draw the line. I try to be accessible to my students in various ways. Currently, social media is the method that seems to work the most effectively. I have two Twitter accounts. One is for personal use and one is for my classes. To begin with I only had one account and I used it only for my classes. As I began using Twitter for personal postings I realized I did not want my students to be "subjected" to my personal postings. I am a Christian and many of my personal tweets dealt with Biblical quotes and inspiration sayings. I realized that it was not appropriate for me to put these types of messages on something my students were encouraged to read. I didn't want them to feel like I was forcing my faith and beliefs on them. At that point, I began a separate account for my classes. Personally, if a student asks to be my friend on Facebook or Twitter, I am fine with accepting their request. This is their choice. I don't feel that I as a teacher should ask them to "friend" me. They might feel that if they don't accept my request their grade could be in jeopardy. I don't feel that it is appropriate to put information concerning grades on social media (March 6, 2014).

\section{Summary}

The intent of this study was to look at how faculty in a mid-Atlantic Community College were using social media with their students and were they aware of the potential for issues with FERPA. A modified Delphi study was used to conduct the research. This form of research starts with a first survey and based on the information gathered in the first survey, a second set of 
survey questions were generated and sent to gather further information. This is typically a three or four survey process with the last one usually ending in interviews while trying to reach consensus. This study was looking for commonalities among the faculty and their use of social media with their students.

The study showed faculty are generally using social media with their students and faculty are confused regarding the potential issue of FERPA violations when communicating with their students in this manner. Chapter Five will discuss the potential for further research on this subject. 


\section{Chapter 5}

The purpose of this study was to examine the use of online social media by faculty in community colleges and their awareness of privacy issues regarding FERPA. This exploratory study investigated how community college faculty were using social media for teacher-student communication, what technologies were being used, and whether faculty were aware of FERPA issues that could be violated by the use of social media. Participants in this study were faculty from a mid-Atlantic Community College with a Carnegie Classification of Public, 4-year or above, Associate dominate with an enrollment profile of exclusively undergraduate four-year. The institution offers certificates; associate degree programs; and was the first (1989) of only fifty-four colleges in the nation to be accredited to offer baccalaureate degrees (Russell, 2010, p. 7). The institution had an enrollment of approximately 3900 students (Carnegie Foundation, 2012).

As noted in chapter one, Diaz wrote about "the explosion of cloud-based or Web 2.0 technologies" (2011). The use of social media continues to grow at a rapid pace. Facebook currently has 1.1 billion active users monthly with daily users averaging 655 million (Facebook 2013). Over 554,750,000 million Twitter accounts have opened of May 7, 2013, and it is estimated there are 58-million tweets on average a day (Twitter (2013). As of March 2013, LinkedIn had 255 million members with more than two professionals per second signing to join (LinkedIn (2010). Sturgeon \& Walker found $75 \%$ of faculty were concerned about the balance between students and faculty when using social media (p.4) and then there is the potential for FERPA violations if faculty publish something that can identify a student's records (Dec. 2011, p. 75649). 
The study completed each year by Pearson demonstrates the increase in the use of many different forms of social media by faculty (2012). These studies, however, do not look at the potential for FERPA violations or for faculty awareness that could be a problem for them. FERPA is the Federal Educational Rights and Privacy Act that only allows certain student directory information to be released publically or with written consent by the student, and in some cases, the parent. When faculty post student information on a social media site, and it can lead to identification of the student, then they are in violation of FERPA. The research questions that guided this exploratory study were:

RQ 1: How are faculty using social media for teacher-student communications?

RQ 2: Are there privacy concerns faculty should be aware of because of the Federal Education Rights to Privacy Act?

RQ3: What social media is being used by faculty to communicate with students?

This study was necessary to determine how faculty in community colleges are using social media with their students. Faculty posting student information that is not approved by FERPA put the college at risk for losing federal funding. It was just as important to know if faculty were aware of the potential for FERPA violations or if their college had a social media policy. It is critical for administration to consider creating guidelines for faculty use of social media with their students to prevent problems in the future.

This study was necessary to determine if faculty were using social media to communicate with students in a way that violates FERPA. The results of this study can help administrators better understand the need for policy regarding faculty use of social media and can help clarify what that policy needs to be. Ball State University and Depaul have already established 
guidelines. Ball State's policy states that privacy does not exist in the social media world (2009, 2006). A modified Delphi Method was used for data collection for this study. It requires a group of "experts in their field" to respond to a survey where similar answers can be compiled to eventually work towards consensus in the project being discussed. After the first round, additional surveys were sent to participants and the information was collected and processed into the different areas of consensus thus eventually ending up with one (or only a few) solutions for the project (Rand Corporation (n.d.), Delphi Method). For this study, consensus was not the goal, but instead commonalities of usage between community college faculty and social media and their awareness regarding FERPA were examined.

The first research question looked at how faculty are using social media for teacherstudent communication. These questions were based on a survey previously conducted by Magna Publications, via Faculty Focus in the spring of 2011 distributed to over 1000 faculty members in higher education. A second survey was modified based on answers to Survey One and then resent to the respondents of Survey One. Those faculty that met predetermined criteria based on answers to the second survey were interviewed to discuss their use of social media with their students and their awareness of FERPA.

The research was consistent with the study completed by Pearson in 2012 that found $33.8 \%$ of faculty are using social media for teaching purposes (p. 16). Teaching purposes can be something as simple as posting assignments for students on social media. While this is not a direct form of communication, as there will typically not be any back and forth comments, there is still the potential for a FERPA violation to occur. If a student comments on the post and the teacher responds, then the teacher has inadvertently let others know the student is in his or her course. Thirty-seven percent of faculty in this research study currently have friends that are 
current students on social media. One of the interviewees responded they try to be "accessible to their students in various ways and currently social media seems to work the most effectively".

The second research question asked if there were privacy concerns faculty should be aware of because of the Federal Education Rights to Privacy Act. The response to this question was not consistent with the research in the literature review. Sixty-four percent of faculty in the Pearson study had concerns about privacy issues with social media but none expressed concerns regarding FERPA (Pearson 2012, P. 27). While 73\% (N=16) of the faculty in this study were aware of FERPA that does not mean they know the guidelines for violation of FERPA. Faculty need to be careful of information they share publicly about their students because FERPA regulations apply. Any information that can potentially identify a student is prohibited (2011, Federal Register). Fifty-nine $(\mathrm{N}=13)$ percent of respondents in this study did not know whether the college had a social media policy, while fourteen percent $(\mathrm{N}=3)$ thought there was a policy but there is nothing in the Answer Book regarding need social media policy at the institution where the research was conducted (Answer Book, 2014). In addition to faculty posting inappropriate things on social media, FERPA should be a major concern when they post information with students. Faculty respondent F3, when given a list of five FERPA violations, commented that possibly one of them was in violation. Faculty know there are "rules" but they don't know what they are.

The research is consistent with previous studies and it provides data that seems to answer research question number three: What social media is being used by faculty to communicate with students? Prior studies conducted showed faculty using LinkedIn (24\%), Facebook (19\%), and Twitter (5\%) for professional use. In this study, faculty $(63 \%, \mathrm{~N}=14)$ considered students in their professional use of social media. While the social media sites are the same for this study as the 
Pearson study referred to in chapter two, the rankings of social media are slightly different as the percentages for Facebook use is much higher. The most used sites in this particular study showed community college faculty were using Facebook $(69 \%, \mathrm{~N}=11)$, GooglePlus+ $(25 \%, \mathrm{~N}=4)$ and LinkedIn $(6 \%, \mathrm{~N}=1)$ with none of them using Twitter.

\section{Implications}

\section{Recommendation from the research}

- Institutions need to consider adopting a social media policy that deals with the potential issues of FERPA violations and the use of social media between faculty and students.

- The Community and Technical College system at the state level needs to consider adopting a social media policy that deals with the potential issues of FERPA violations and the use of social media between faculty and students.

- Faculty and students need to have a better understanding of the use of social media and the potential for harm. Once something is posted on social media it is there for all the world to see.

- Faculty need to be made aware of what constitutes violations of FERPA. While participants in this study knew about FERPA, those interviewed were confused as to what actually constituted a violation.

- Faculty need to be instructed in social media policy once it is developed.

- Faculty need to be introduced to social media and taught to use it responsibly. It has the potential for faculty to make a connection with students that can lead to retention.

- With the high cost of a formal LMS system, social media, when used properly is potentially a less expensive resource for student education. 


\section{Recommendations for further research}

- How other countries are using social media in the classroom and what can we learn from them?

- What kind of "policing" is necessary for colleges using social media in the classroom?

- With technology advancing as quickly as it is, the social media used will be ever changing. Learning the technology of the future should be ongoing.

- How do we get faculty to use social media with students?

- How are different institution "types" using social media?

- Which fields of study are more susceptible to use of social media and violations?

- What effect will FERPA reform have on faculty use of social media?

- Who owns the information shared on social media - the intellectual property rights?

\section{Summary}

This study looked at how faculty in a mid-Atlantic community college were using social media with students and if they were aware of FERPA. Seventy-eight $(N=25)$ percent of faculty use social media in some form or another and $47 \%(\mathrm{~N}=9)$ reported they had "friended" a student on social media. Fourteen $(\mathrm{N}=3)$ percent thought there was a social media policy at the college when in fact there was not a policy. When the interview questions were presented with five FERPA violations the respondents did not consider the statements to be in violation. This demonstrates to the researcher there is a need for social media policy in the community college system. There is a need for faculty to be made aware of the kinds of things that create FERPA violations. Issues such as legal ramifications and funding repercussions can be created when faculty posts privileged communications regarding students. The researchers conclusions are that faculty are using social media with their students, this relationship will continue to grow, and if 
the college does not have some kind of a social media policy or faculty training regarding FERPA then problems will inevitably arise. 


\section{References}

Bart, M. (2011). Social media trends among higher education faculty. Faculty Focus. Magna Publications. Retrieved from www.facultyfocus.com 2/12/2012.

Black, E. W., Beck, D., Dawon, K., Jinks, S, \& DiPietro, M. (2007). Considering implementation and use in the adoption of an LMS in online and blended learning environments. TechTrends, 51(2) 35-39. DOI:1010\%0\%7/s11528-007-0024-x or http://link.springer.com/article/1010\%0\%7\%2Fs11528-007-0024-x?LI=true

boyd, d. m., \& Ellison, N. B. (2007). Social network sites: Definition, history and scholarship. Journal of Computer-Mediated Communication 13(1), 210-230. DOI:10.1111/j10\%83610120\%070\%393.x or http://jcmc.indiana.edu/vol13/issue1

Brock, R. \& Young, J. R. (2006, August 4). Facebook and other social-networking sites raise questions for administrators. Chronicle of Higher Education 52(48\%), 37.

Carnegie Foundation for Advancement of Teaching. (2010). retrieved from http://classifications.carnegiefoundation.org/lookup_listings/view_institution.php?unit_id $=237686 \&$ start_page=institution.php\&clq=\%7B $\% 22$ ipug2005 ids $\% 22 \% 3 \mathrm{~A} \% 22 \% 22 \% 2$ C\%22ipgrad2005_ids\%22\%3A\%22\%22\%2C\%22enrprofile2005_ids\%22\%3A\%22\%22 \%2C\%22ugprfile2005_ids\%22\%3A\%22\%22\%2C\%22sizeset2005_ids\%22\%3A\%22\%22 \%2C\%22basic2005 ids\%22\%3A\%22\%22\%2C\%22eng2005 ids\%22\%3A\%22\%22\%2C \%22search_string\%22\%3A\%22West+Virginia+University+Parkersburg\%22\%2C\%22lev el $\% 22 \% 3 \mathrm{~A} \% 22 \% 22 \% 2 \mathrm{C} \% 22 \mathrm{control} \% 22 \% 3 \mathrm{~A} \% 22 \% 22 \% 2 \mathrm{C} \% 22 \mathrm{accred} \% 22 \% 3 \mathrm{~A} \% 22 \% 2$ 2\%2C $\% 22$ state $\% 22 \% 3 \mathrm{~A} \% 22 \% 22 \% 2 \mathrm{C} \% 22$ region $\% 22 \% 3 \mathrm{~A} \% 22 \% 22 \% 2 \mathrm{C} \% 22$ urbanicity \%22\%3A\%22\%22\%2C\%22womens $\% 22 \% 3 \mathrm{~A} \% 22 \% 22 \% 2 \mathrm{C} \% 22 \mathrm{hbcu} \% 22 \% 3 \mathrm{~A} \% 22 \% 22$ \%2C $\% 22 \mathrm{hsi} \% 22 \% 3 \mathrm{~A} \% 22 \% 22 \% 2 \mathrm{C} \% 22$ tribal\%22\%3A $\% 22 \% 22 \% 2 \mathrm{C} \% 22 \mathrm{msi} \% 22 \% 3 \mathrm{~A}$ $\% 22 \% 22 \% 2 \mathrm{C} \% 22$ landgrant $\% 22 \% 3 \mathrm{~A} \% 22 \% 22 \% 2 \mathrm{C} \% 22$ coplac $\% 22 \% 3 \mathrm{~A} \% 22 \% 22 \% 2 \mathrm{C} \%$ 22urban $\% 22 \% 3 \mathrm{~A} \% 22 \% 22 \% 7 \mathrm{D}$.

Carter, H. L., Foulger, T. S., \& Ewbank, A. D. (2008). Have you googled your teacher lately? Teachers' use of social networking sites. Phi Delta Kappan, 89(9). 681-685. Retrieved from http://www.pdkintl.org/kappan/ktoc.htm 
Chen, B., \& Bryer, T. (2012). Investigating instructional strategies for using social media in formal and informal learning. The International Review of Research in Open and Distance Learning, 13(1). 87-104. Retrieved from http://www.irrodl.org

Diaz, V. (2011). Cloud-based technologies: Faculty development, support, and implementation. Journal of Asynchronous Learning Networks, 15(1). 95-102. Retrieved from http://sloanconsortium.org/jaln/v15n1/cloud-based-technologies-faculty-developmentsupport-and-implementation

Delbecq, A. L., Van de Ven, A.H., \& Gustafson, D. H., (1975)__Group techniques for program planning: A guide to nominal group and delphi processing. London, UK: Longman Higher Education. DOI. 101-499-651 (Last edited on 2002/06/26 14:40:56 GMT-6)

Electronic Code of Federal Record. (2014). Title 34 - Education. SS 99.3. Retrieved from http://www.ecfr.gov/cgibin/retrieveECFR?gp=1\&SID=0fae4ddad19fe69a1 ef061c3b245a52a\&ty=HTML\&h=L\& $\underline{\mathrm{r}=\mathrm{SECTION} \& \mathrm{n}=32 \mathrm{y} 3.1 .1 .1 .8 .5 .11 .1}$

Estrada, A. W. (2010). Saving face from facebook: Arriving at a compromise between schools' concerns with teacher social networking and teachers' first amendment rights. Thomas Jefferson Law Review, 32(2), 283-312. Retrieved from http://content.ebscohost.com.www.libproxy.wvu.edu/pdf23_24/pdf/2010/3BP/01Apr10/5 2817774.pdf?T $=\mathrm{P} \& \mathrm{P}=\mathrm{AN} \& \mathrm{~K}=52817774 \& \mathrm{~S}=\mathrm{R} \& \mathrm{D}=\mathrm{a} 9 \mathrm{~h} \&$ EbscoContent $=\mathrm{dGJ}$ MMvl7E Sep7Y4xNvgOLCmr0ueqK9Ssqa4SbWWxWXS\&ContentCustomer=dGJyMPXs54rz5O eOuePfgeyx44Dt6fIA

Facebook. (n.d.). Facebook.About. Retrieved March 25, 2013 from https://www.facebook.com/facebook/about

Hand, M. (2011). Living publicly on campus: Social media and its discontents. Academic Matters, Oct-Nov 2011. Retrieved from http://www.academicmatters.ca/printissues/policing:relationships-on-campus/

Hatcher, T., \& Colton, S. (2007). Using the internet to improve HRD research. The case of the web-based delphi research technique to achieve content validity of an HRD-oriented 
measurement. Journal of European Industrial Training, 31(7)570-587. DOI:

$\underline{10.1108 / 03090590710820060}$ or http://dx.doi.org/10.1108/03090590710820060

Hecht, A. B. (1977). A modified Delphi technique for obtaining consensus on institutional research priorities. Retrieved from http://content.ebscohost.com.www.libproxy.wvu.edu/pdf23_24/pdf/2010/3BP/01Apr10/5 2817774.pdf?T=P\&P=AN\&K=52817774\&S=R\&D=a9h\&EbscoContent=dGJyMMv17E Sep7Y4xNvgOLCmr0ueqK9Ssqa4SbWWxWXS\&ContentCustomer=dGJyMPXs54rz5O eOuePfgeyx44Dt6fIA

Hsu, C., \& Sandford, B. A. (2007). The delphi technique: Making sense of consensus. Practical Assessment, Research \& Evaluation, 12(10), 1-8. Retrieved from http://pareonline.net/pdf/v12n10.pdf

Hughes, T. (2001). Releasing student information: What's public and what's not. School Law Bulletin/Winter 2001 (pp 12-29).

Johnson, D. (2012). 5 steps to connecting with the movers and shakers on LinkedIn. http://socialmediatoday.com/davidjohnson4/443784/linkedin-5-steps-connecting-moversand-shakers

Johnson, S. (2009, June 5). How twitter will change the way we live. Time. Retrieved from http://www.time.com/time/printout/0,8816,1902604,00.html

Junco, R., (2010). Why I don't trust that facebook will keep your child's information private. Social Media In Higher Education. [Web blog post]. Retrieved from http://blog.reyjunco.com/why-i-dont-trust-that-facebook-will-keep-your-childsinformation-private

Junco, R., \& Chickering, A. W. (2010). Civil discourse in the age of social media. About Campus, 15(4), 12-18. DOI:1010\%0\%2/abc20\%030 or http://dx.doi.org/1010\%0\%2/abc20\%030 
Knibbs, K. (2014). The comprehensive guide to facebook privacy settings. Techlicious. Retrieved from http://www.techlicious.com/guide/the-guide-to-facebook-privacysettings-2013/. Para 1.

LinkedIn, (n.d.). LinkedIn About. Retrieved March 25, 2013 from http://www.linkedin.com/about-us

Lupsa, C. (2006, December 13). A campus fad becomes a campus fact. Christian Science Monitor 99(13). Retrieved from http://www.csmonitor.com/2006/1213/p13s01-legn.html

Mabrouk, P. A. (2009). Practical and effective networking. Analytical \& Bioanalytical Chemistry, 395(1) 1-4. DOI: 1010\%0\%7/s00216-009-2946-y or http://link.springer.com/article/1010\%0\%7\%2Fs00216-009-2946-y

Marisico Jr., E. M. (2010). Social Networking websites: Are myspace and facebook the fingerprints of the twenty-first century? Widener Law Journal, 19(3) 967. Retrieved from http://connection.ebscohost.com/c/articles/51467991/social-networking-websites-aremyspace-facebook-fingerprints-twenty-first-century

Maryott, M. L. (2010). Social networking in the workplace creates peril for employers. In-House Litigator, 24(3) p. 3. Retrieved from http://search.ebscohost.com.www.libproxy.wvu.edu/login.aspx?direct=true $\& d b=a 9 h \& A$ $\underline{\mathrm{N}=51913891 \& \text { site }=\text { ehost-live, }}$

Merriam-Webster Dictionary. 2013. Retrieved from http://www.merriamwebster.com/dictionary/networking?show $=0 \& \mathrm{t}=1370910105$ (610\%13\%)

Moran, M., Seaman, J., \& Tinti-Kane, H. (2012). Blogs, wikis, podcasts and facebook: How today's higher education faculty use social media. Retrieved from http://www.pearsonlearningsolutions.com/assets/downloads/pdfs/pearson-social-mediasurvey-2012-bw.pdf

Nelson, A. J. (2002). Using a modified delphi methodology to develop a competency model for vet practitioners. Advanced Study in Research Methods. Retrieved from http://amynelson.efoliomn.com/Uploads/RM502EPaper.pdf 
Rice, A. (2011). Georgia Tech wipes class wikis from web. The Chronicle of Higher Education. (np). Retrieved from http://chronicle.com/blogs/wiredcampus/georgia-tech-wipescomputing-class-wikis-from-web/34364

Rowe, G., \& Wright, G. (1999). The Delphi technique as a forecasting tool: issues and analysis. International journal of forecasting, 15(4) p. 353-375. DOI:org/1010\%16/S01692070(99)00018-7 or http://www.sciencedirect.com/science/article/pii/S0169207099000187.

Schwartz, H. L. (2010). Facebook: The new classroom commons? Education Digest, 75(5). P. 39-42. Retrieved from http://search.ebscohost.com.www.libproxy.wvu.edu/login.aspx?direct=true $\& \mathrm{db}=$ eric $\& A$ $\mathrm{N}=\mathrm{EJ}$ 873643\&site=ehost-live

Sturgeon, C., \& Walker, C. (2009, March 29-31). Faculty on facebook: Confirm or deny? Study presented at $14^{\text {th }}$ Instructional Technology Conference Murfreesboro, TN.

Talbert, R., (2008, November 20). Publicly exposing cheaters? The Chronicle of Higher Education,( Np). Retrieved from http://chronicle.com/blognetwork/castingoutnines/2008/11/20/publicly-exposingcheaters/

Twitter. (n.d.) Twitter About.. Retrieved March 25, 2013 from http://twitter.com/about.

U.S. Department of Education. (2008). Family educational rights and privacy; Final Rule. Federal Register, 73(237) 74806-74855. Retrieved from http://www2.ed.gov/legislation/FedRegister/finrule/2008-4/120908a.pdf

U.S. Department of Education. (2011). Family educational rights and privacy act. Federal Register, 76(232) 75604-75660. Retrieved from http://www2.ed.gov/policy/gen/guid/fpco/ferpa/index.html

Wolff, H., \& Moser, K. (2009). Effects of networking on career success: A longitudinal study. Journal of Applied Psychology, 94(1), 196-206. DOI:1010\%37/a0013350 or http://www.ncbi.nlm.nih.gov/pubmed/19186904 
Workman, T. A. (2008, September 19). The real impact of virtual worlds. The Chronicle Review. 55(4), 12. Retrieved from http://chronicle.com/article/The-Real-Impact-of-Virtual/22188 


\section{Appendix A}

Request to use boyd \& Ellison figure

S Dianne Davis <sdavis6@wvup.edu>

to epiper, bcc: me

Dear Mr. Piper,

I am a 64-year old doctoral student working on my dissertation. I am looking at Faculty awareness and use of FERPA. In my paper I am doing a timeline of social media and would love to be able to use the Online Social Networking timeline in the boyd and Ellison article Social Network Sites: Definition, History, and Scholarship. It looks like it was created by Nicole Ellison and she said I should contact you. Thank you in advance for any help you can give me.

Dianne

S. Dianne Davis, ABD

Associate Professor

Online Business Technology Coordinator

Honor's College Coordinator

Phi Theta Kappa Advisor

Piper, Eric - Boston <epiper@wiley.com>

to me

Dear Dianne,Thank you for your email and best of luck to you in finishing your PhD. We are happy to grant you gratis permission to reuse the requested figure in your dissertation. We just ask that you make the standard acknowledgement in your paper.

Please don't hesitate to contact me if I can be of further assistance.

Sincerely,

Eric 


\section{Appendix B}

\section{Parkersburg}

West VirginiaUniversity.

S Dianne Davis <sdavis6@wvup.edu>

\section{Fwd: RE: Question regarding use of survey}

1 message

Dianne Davis <Dianne.Davis@mail.wvu.edu> Tue, Apr 23, 2013 at 12:59 PM

To: sdavis6@wvup.edu

> > On 2/20/2013 at 8:59 AM, in message

<CB46BA98A4DE7C46BBBB42D2247004B503658764@magna-sbs.Magnapubs.local>, "Bart, Mary"

<mary.bart@facultyfocus.com> wrote:

Hi Dianne,

You have our permission to use the same survey questions. Good luck with your dissertation I'd love to see some of the results of your findings once it's all completed.

Regards,

Mary

Mary Bart

Editor

Faculty Focus

Magna Publications

(608) 227-8107

www.FacultyFocus.com

Twitter: https://twitter.cam/facultyfacus

Facebouk: https://www.facebouk.com/TeachingProfessar

Linkedln: http://www.linkedin.com/in/marybart

My research is looking at how faculty use social media and are they aware of FERPA issues that can come about because of their use. My main reason for wanting to use your questions is so I don't have to do a "trial test" as it has already been done. (I hope that makes sense).

Thank you in advance for talking with me either way. lol 


\section{Appendix C}

\section{Initial email script}

Dear Participant,

This email is a request for you to take part in a research project to assess how faculty are using online social media. This project is being conducted by S. Dianne Davis, a doctoral candidate in Higher Education Leadership at WVU under the supervision of Terence C. Ahern, Associate Professor in the College of Education and Human Services. This research is being conducted as part of her doctoral requirements.

Your participation in this project is greatly appreciated. It is entirely online and will take approximately 10 minutes to complete. Initially you will fill out a short survey regarding your use of online social media; then you will respond to 2.more surveys depending on your answers to the previous survey. The surveys involve asking you about your teaching and use of online social media to communicate with students. They will be used to help identify potential privacy issues with the use of online social media and the Federal Education Right of Privacy Act and the potential for policy at the institutional level.

Your involvement in this project will be kept confidential as legally possible. All data collected will be reported in the aggregate. You must be 18 years of age or older to participate. I will not ask any information that could identify you as a participant and you may discontinue the project at any time. West Virginia University's Institutional Review Board is aware of this research.

I hope that you will participate in this research project, as it could be beneficial in understanding faculty awareness of privacy issues such as FERPA in an online social environment and the potential need for institutional policy. If you agree to participate, simply respond to this email. Once I receive your reply to participate I will send further information on how to log into the Study. Your name will be entered into a drawing for the opportunity to win a $\$ 25$ gift card for your participation in this project.

Thank you very much for your time.

Should you have any questions about this letter or the research project, please feel free to cont-act Terence C. Ahern by email at terence.ahern@mail.wvu.edu, or phone at 304 293-3804. S. Dianne Davis can be contacted by email at sdavis6@wvup.edu or by phone at 304-588-1380 .

S. Dianne Davis 


\section{Email Script}

Dear Participant,

Thank you for agreeing to take part in the second phase of this research project. This project is being conducted by S. Dianne Davis, a doctoral candidate in Higher Education Leadership at WVU under the supervision of Terence C. Ahern, Associate professor in the College of Education and Human Services.

To log on to the second survey click here: IDT Study. You will need to enter your credentials as indicated below:

\section{Username: KKKKKK}

Password: XXXXXX

Remember your participation is voluntary. You may skip any question that you do not wish to answer and you may discontinue at any time. Your name will be entered into a drawing for the opportunity to win a $\$ 25$ gift card for your participation in this project. Your chances of winning will be greater as there aren't as many recipients for the second round of surveys.

This research could be beneficial in understanding how faculty are using online social media to communicate with students and their awareness of potential privacy issues such as violation of the Federal Education Right of Privacy Act that could result in a need for institutional policy.

Thank you very much for your time. Should you have any questions about this letter or the research project, please feel free to contact Terence C. Ahern by email at terence.ahern@mail.wvu.edu, or phone at 304 293-3804.

Thank you.

S. Dianne Davis

Sdavis6@wvup.edu

$304588-1380$ 
Interview Letter

Dear Faculty,

I really appreciate your willingness to participate in the previous surveys regarding your use of social media for my study "Exploring the use of Social Media and its effect on policy in Community Colleges". Your participation has allowed me to gather insightful data on your opinions and use of social media in Community Colleges.

I am in the final stage of data gathering, the interview, and need your help one last time. Out of the original population of 200 participants, I have narrowed the field to five. You are one of the five who met my pre-determined interviewee criteria. 1. Faculty using social media 2. Faculty having students as friends on social media. 3. Faculty not aware of potential FERPA issues from using social media.

I would like to invite you to an interview in which we will discuss:

1. Your current use of social media.

2. The policies that govern the use of social media in your community college.

3. The best practice models in place regarding your use of social media.

4. The barriers that impede your use/implantation of social media.

5. Your knowledge of FERPA in regards to communications with students through social media.

6. Your overall feelings regarding faculty use of social media regarding FERPA issues.

I estimate the interview will last approximately 30-45 minutes. I understand that each of you are extremely busy, so I would like to use Gotomeeting.com to facilitate this interview. If you haven't used this technology before, you simply login to a website and you will be able to see my presentation as we conduct the interview. You will also phone a conference call number that will allow the of us (the interviewees + myself) to talk to each other.

Again, because you are all so busy, I would like to add an incentive. Each of you will be registered to win a \$25 Visa Gift Cards. Please consider participating once more. I would like to schedule this interview next to be determined. Can you please respond to this email and let me know if you are available so that I can send you the link for gotomeeting.com? Again, thank you for your participation and I hope to hear from you.

Should you have any questions about this letter or the research project, please feel free to contact Terence C. Ahern by email at terence.ahern@mail.wvu.edu, or phone at 304 293-3804. S. Dianne Davis can be contacted by email at sdavis6@wvup.edu or by phone at 304-588-1380 


\section{Appendix D}

My Report

Last Modified: 03/15/2014

\section{What is your role in higher education?}

\begin{tabular}{|c|l|c|c|c|}
\hline$\#$ & Answer & & Response & $\%$ \\
\hline 1 & instructor & & 23 & $44 \%$ \\
2 & $\begin{array}{l}\text { Associate } \\
\text { Professor }\end{array}$ & & 8 & $15 \%$ \\
\hline 3 & Assistant & Professor & 7 & $13 \%$ \\
\hline 4 & Full Professor & Total & 52 & $27 \%$ \\
\hline & & 14 & $100 \% \%$ \\
\hline
\end{tabular}

Statistic

Value

Min Value

Max Value

Mean

Variance

Standard Deviation

\section{How many years have you worked in higher education?}

\begin{tabular}{|c|l|c|c|c|}
\hline$\#$ & Answer & Response & $\%$ \\
\hline 1 & less than one & year & 5 & $0 \%$ \\
\hline 2 & $1-2$ years & 9 & $10 \%$ \\
3 & 3-5 years & 38 & $17 \%$ \\
4 & more than 5 & $73 \%$ \\
\hline & years & 52 & $100 \% \%$ \\
\hline
\end{tabular}




\section{What is your designation?}

\begin{tabular}{|c|l|c|c|c|}
\hline$\#$ & Answer & & Response & $\%$ \\
\hline 1 & term faculty & & 28 & $55 \%$ \\
2 & tenure track & 1 & $2 \%$ \\
3 & tenured & 14 & $27 \%$ \\
4 & instructional & & 8 & $16 \%$ \\
\hline & specialist & Total & 51 & $100 \% \%$ \\
\hline
\end{tabular}

Statistic

Min Value

Max Value

Mean

Variance

Standard Deviation

\section{What is your gender?}

\begin{tabular}{|c|l|c|c|c|}
\hline$\#$ & Answer & & Response & $\%$ \\
\hline 1 & Male & & 22 & $42 \%$ \\
2 & Female & & 30 & $58 \%$ \\
\hline & Total & & 52 & $100 \% \%$ \\
\hline
\end{tabular}

\section{Statistic}

Min Value

Max Value

Mean

Variance

Standard Deviation

\section{Are you full time faculty or adjunct?}

\begin{tabular}{|c|l|c|c|c|}
\hline$\#$ & Answer & & Response & $\%$ \\
\hline 1 & Full time & & 36 & $69 \%$ \\
2 & Adjunct & & 16 & $31 \%$ \\
\hline & Total & 52 & $100 \% \%$ \\
\hline
\end{tabular}




\section{Statistic}

Min Value

Max Value

Mean

$131 \%$

Variance

$022 \%$

Standard Deviation

\begin{tabular}{c|l|c|c|c|}
\hline 6. How often do you use the following social media tools:FACEBOOK \\
\hline$\#$ & Answer & Response & $\%$ \\
\hline 1 & Never & 17 & $33 \%$ \\
2 & Monthly & 4 & $8 \%$ \\
3 & Weekly & 8 & $15 \%$ \\
4 & Daily & 20 & $38 \%$ \\
5 & Check it every & 3 & $6 \%$ \\
\hline & opportunity & 52 & $100 \% \%$ \\
\hline
\end{tabular}

\section{Statistic}

Value

Min Value

Max Value

Mean

Variance

Standard Deviation

\section{How often do you use LinkedIn?}

\begin{tabular}{|c|l|l|c|c|}
\hline$\#$ & Answer & & Response & $\%$ \\
\hline 1 & Never & & 26 & $51 \%$ \\
2 & Monthly & 13 & $25 \%$ \\
3 & Weekly & 6 & $12 \%$ \\
4 & Daily & 5 & $10 \%$ \\
\hline 5 & Check it every & 1 & $2 \%$ \\
\hline & opportunity & 51 & $100 \% \%$ \\
\hline
\end{tabular}




\section{Statistic}

Min Value

Max Value

Mean

Variance

Standard Deviation

\section{How often do you use Twitter?}

\begin{tabular}{|c|l|l|c|c|}
\hline$\#$ & Answer & & Response & $\%$ \\
\hline 1 & Never & & 42 & $81 \%$ \\
2 & Monthly & 3 & $6 \%$ \\
3 & Weekly & 4 & $8 \%$ \\
4 & Daily & 2 & $4 \%$ \\
5 & Every & 1 & $2 \%$ \\
\hline & opportunity & 52 & $100 \% \%$ \\
\hline
\end{tabular}

\section{Statistic}

Min Value

Max Value

Mean

Variance

\section{How often do you use Moodle?}

\begin{tabular}{|c|l|c|c|c|}
\hline$\#$ & Answer & & Response & $\%$ \\
\hline 1 & Never & & 47 & $90 \%$ \\
2 & Monthly & 1 & $2 \%$ \\
3 & weekly & 3 & $6 \%$ \\
4 & Daily & 1 & $2 \%$ \\
\hline 5 & Check it at & & 0 \\
\hline & every & & $0 \%$ \\
\hline & opportunity & Total & 52 & $100 \%$ \\
\hline
\end{tabular}




\section{Statistic}

Min Value

Max Value

Mean

$119 \%$

Variance

0.39

Standard Deviation

\section{How often do you use Pinterest?}

\begin{tabular}{|c|l|l|c|c|}
\hline$\#$ & Answer & & Response & $\%$ \\
\hline 1 & Never & 35 & $69 \%$ \\
2 & Monthly & 11 & $22 \%$ \\
3 & Weekly & 1 & $2 \%$ \\
4 & Daily & 4 & $8 \%$ \\
\hline 5 & Check it every & 0 & $0 \%$ \\
\hline & opportunity & Total & 51 & $100 \% \%$ \\
\hline
\end{tabular}

Statistic

Min Value

Max Value

Mean

Variance

0.77

Standard Deviation

0.88

Total Responses

\section{How often do you use MySpace?}

\begin{tabular}{|c|l|c|c|c|}
\hline$\#$ & Answer & & Response & $\%$ \\
\hline 1 & Never & 52 & $100 \% \%$ \\
2 & Monthly & 0 & $0 \%$ \\
3 & Weekly & 0 & $0 \%$ \\
\hline 4 & $\begin{array}{l}\text { Check it at } \\
\text { every }\end{array}$ & opportunity & 0 & $0 \%$ \\
\hline 5 & Daily & & 0 & $0 \%$ \\
\hline & Total & 52 & $100 \% \%$ \\
\hline
\end{tabular}




\section{Statistic}

Min Value

Max Value

Mean

$10 \%$

Variance

$00 \%$

Standard Deviation

\section{How often do you use Google Plus+}

\begin{tabular}{|c|l|l|c|c|}
\hline$\#$ & Answer & & Response & $\%$ \\
\hline 1 & Never & & 34 & $65 \%$ \\
2 & Monthly & 4 & $8 \%$ \\
3 & Weekly & 8 & $15 \%$ \\
\hline 4 & Check it every & 0 & $0 \%$ \\
\hline 5 & opportunity & Daily & 6 & $12 \%$ \\
\hline & Total & 52 & $100 \% \%$ \\
\hline
\end{tabular}

\section{Statistic}

Min Value

Max Value

Mean

Variance

Standard Deviation

\section{How often do you use DeviantArt?}

\begin{tabular}{|c|l|c|c|c|}
\hline$\#$ & Answer & & Response & $\%$ \\
\hline 1 & Never & 51 & $98 \%$ \\
2 & Monthly & 1 & $2 \%$ \\
3 & Weekly & 0 & $0 \%$ \\
\hline 4 & $\begin{array}{l}\text { Check it at } \\
\text { every }\end{array}$ & & 0 & $0 \%$ \\
\hline 5 & opportunty & Daily & 0 & $0 \%$ \\
\hline & Total & 52 & $100 \%$ \\
\hline
\end{tabular}




\section{Statistic}

Min Value

Max Value

Mean

Variance

Standard Deviation

\section{How often do you use LiveJournal?}

\begin{tabular}{|c|l|c|c|c|}
\hline$\#$ & Answer & & Response & $\%$ \\
\hline 1 & Never & & 51 & $98 \%$ \\
2 & Monthly & 0 & $0 \%$ \\
3 & Weekly & 1 & $2 \%$ \\
\hline 4 & Check it at & every & 0 & $0 \%$ \\
\hline 5 & opportunity & Daily & 0 & $0 \%$ \\
\hline & Total & & $0 \%$ & $100 \%$ \\
\hline
\end{tabular}

\section{Statistic}

Min Value

Max Value

Mean

Variance

Standard Deviation

\section{How often do you use Tagged?}

\begin{tabular}{|c|l|c|c|c|}
\hline$\#$ & Answer & & Response & $\%$ \\
\hline 1 & Never & & 52 & $100 \% \%$ \\
2 & Monthly & 0 & $0 \%$ \\
3 & Weekly & & 0 & $0 \%$ \\
\hline 4 & Check it at & every & 0 & $0 \%$ \\
\hline 5 & opportunity & Daily & 0 & $0 \%$ \\
\hline & Total & 52 & $100 \% \%$ \\
\hline
\end{tabular}


Statistic

Min Value

Max Value

Mean

$10 \%$

Variance

$00 \%$

Standard Deviation

\section{How often do you use Orkut?}

\begin{tabular}{|c|l|c|c|c|}
\hline$\#$ & Answer & & Response & $\%$ \\
\hline 1 & Never & 52 & $100 \% \%$ \\
2 & Monthly & 0 & $0 \%$ \\
3 & Weekly & 0 & $0 \%$ \\
4 & Daily & 0 & $0 \%$ \\
5 & Every & 0 & $0 \%$ \\
\hline & opportunity & Total & 52 & $100 \% \%$ \\
\hline
\end{tabular}

Statistic

Min Value

Max Value

Mean

$10 \%$

Variance

$00 \%$

Standard Deviation

$00 \%$

Total Responses

17. How often do you use CafeMom?

\begin{tabular}{|c|l|c|c|c|}
\hline$\#$ & Answer & & Response & $\%$ \\
\hline 1 & Never & & 52 & $100 \% \%$ \\
2 & Monthly & 0 & $0 \%$ \\
3 & Weekly & 0 & $0 \%$ \\
4 & Daily & 0 & $0 \%$ \\
5 & Every & Opportunity & 0 & $0 \%$ \\
\hline & Total & 52 & $100 \% \%$ \\
\hline
\end{tabular}


Statistic

Min Value

Max Value

Mean

$10 \%$

Variance

$00 \%$

Standard Deviation

\section{How often do you use Ning?}

\begin{tabular}{|c|l|c|c|c|}
\hline$\#$ & Answer & & Response & $\%$ \\
\hline 1 & Never & 52 & $100 \% \%$ \\
2 & Monthly & 0 & $0 \%$ \\
3 & Weekly & 0 & $0 \%$ \\
\hline 4 & every & 0 & $0 \%$ \\
\hline 5 & opportunity & Daily & 0 & $0 \%$ \\
\hline & Total & 52 & $100 \% \%$ \\
\hline
\end{tabular}

Min Value

Max Value

Mean

$10 \%$

Variance

$00 \%$

Standard Deviation

$00 \%$

Total Responses

19. How often do you use Meetup?

\begin{tabular}{|c|l|c|c|c|}
\hline$\#$ & Answer & & Response & $\%$ \\
\hline 1 & Never & & 52 & $100 \% \%$ \\
\hline 2 & Monthly & 0 & $0 \%$ \\
3 & Weekly & 0 & $0 \%$ \\
4 & every & 0 & $0 \%$ \\
\hline 5 & opportunity & Daily & 0 & $0 \%$ \\
\hline & Total & 52 & $100 \%$ \\
\hline
\end{tabular}




\section{Statistic}

Min Value

Max Value

Mean

Variance

$10 \%$

Standard Deviation

\section{How often do you use MyLife?}

\begin{tabular}{|c|l|c|c|c|}
\hline$\#$ & Answer & & Response & $\%$ \\
\hline 1 & Never & 52 & $100 \% \%$ \\
2 & Monthly & 0 & $0 \%$ \\
3 & Weekly & 0 & $0 \%$ \\
4 & every & 0 & $0 \%$ \\
\hline 5 & opportunity & Daily & 0 & $0 \%$ \\
\hline & Total & 52 & $100 \% \%$ \\
\hline
\end{tabular}

\section{Statistic}

Min Value

Max Value

Mean

$10 \%$

Variance

$00 \%$

Standard Deviation

$00 \%$

Total Responses

\section{How often do you use Ask.fm?}

\begin{tabular}{|c|l|c|c|c|}
\hline$\#$ & Answer & & Response & $\%$ \\
\hline 1 & Never & & $48 \%$ & $94 \%$ \\
2 & Monthly & 3 & $6 \%$ \\
3 & Weekly & 0 & $0 \%$ \\
\hline 4 & every & 0 & $0 \%$ \\
\hline 5 & opportunity & Daily & 0 & $0 \%$ \\
\hline & Total & & 51 & $100 \%$ \\
\hline
\end{tabular}




\section{Statistic}

Min Value

Max Value

Mean

$16 \%$

Variance

$06 \%$

Standard Deviation

\section{Approximately how long have you been using these social media}

\section{tools?FACEBOOK}

\begin{tabular}{|c|l|c|c|c|}
\hline$\#$ & Answer & & Response & $\%$ \\
\hline 1 & Never & & 17 & $33 \%$ \\
2 & $<1$ year & 1 & $2 \%$ \\
3 & $1-2$ years & 8 & $16 \%$ \\
4 & $3-5$ years & & 11 & $22 \%$ \\
5 & $>5$ years & & 14 & $27 \%$ \\
\hline & Total & & 51 & $100 \%$ \\
\hline
\end{tabular}

\section{Statistic}

Min Value

Max Value

Mean

Variance

\section{How often have you been using LinkedIn?}

\begin{tabular}{|c|l|l|c|c|}
\hline$\#$ & Answer & & Response & $\%$ \\
\hline 1 & Never & & 25 & $48 \% \%$ \\
2 & $<1$ year & & 9 & $17 \%$ \\
3 & $1-2$ years & & 6 & $12 \%$ \\
4 & 3-5 years & 7 & $13 \%$ \\
5 & $>5$ years & & 5 & $10 \%$ \\
\hline & Total & & 52 & $100 \% \%$ \\
\hline
\end{tabular}




\section{Statistic}

Min Value

Max Value

Mean

Variance

Standard Deviation

\section{How long have you used Twitter?}

\begin{tabular}{|c|l|c|c|c|}
\hline$\#$ & Answer & & Response & $\%$ \\
\hline 1 & Never & & 40 & $78 \%$ \\
2 & $<1$ year & 0 & $0 \%$ \\
3 & 1-2 years & 5 & $10 \%$ \\
4 & 3-5 years & 6 & $12 \%$ \\
5 & $>$ five years & 0 & $0 \%$ \\
\hline & Total & 51 & $100 \%$ \\
\hline
\end{tabular}

\section{Statistic}

Value

Min Value

Max Value

Mean

Variance

$117 \%$

Standard Deviation

Total Responses

\section{How long have you used Moodle?}

\begin{tabular}{|c|l|c|c|c|}
\hline$\#$ & Answer & & Response & $\%$ \\
\hline 1 & never & 45 & $87 \%$ \\
2 & $<1$ year & 2 & $4 \%$ \\
3 & $1-2$ years & 0 & $0 \%$ \\
4 & 3-5 years & 4 & $8 \%$ \\
5 & $>$ five years & 1 & $2 \%$ \\
\hline & Total & 52 & $100 \%$ \\
\hline
\end{tabular}

\section{Statistic}

Mean

Variance 


\section{How often have you used Pinterest?}

\begin{tabular}{|c|l|c|c|c|}
\hline$\#$ & Answer & & Response & $\%$ \\
\hline 1 & Never & 35 & $69 \%$ \\
2 & $<1$ year & 4 & $8 \%$ \\
3 & $1-2$ years & 11 & $22 \%$ \\
4 & $3-5$ years & 1 & $2 \%$ \\
5 & $>5$ years & 0 & $0 \%$ \\
\hline & Total & 51 & $100 \% \%$ \\
\hline
\end{tabular}

Statistic

Min Value

Max Value

Mean

1.57

Variance

0.81

Standard Deviation

\section{How long have you used MySpace?}

\begin{tabular}{|c|l|c|c|c|}
\hline$\#$ & Answer & & Response & $\%$ \\
\hline 1 & Never & 46 & $90 \%$ \\
2 & $<1$ year & 1 & $2 \%$ \\
3 & 1-2 years & 0 & $0 \%$ \\
4 & 3-5 years & 2 & $4 \%$ \\
5 & $>$ five years & 2 & $4 \%$ \\
\hline & Total & 51 & $100 \%$ \\
\hline
\end{tabular}

Min Value

Max Value

Mean

Variance

0.93

Standard Deviation

0.97

Total Responses 


\section{How long have you used Google Plus+}

\begin{tabular}{|c|l|l|c|c|}
\hline$\#$ & Answer & & Response & $\%$ \\
\hline 1 & Never & & 35 & $67 \%$ \\
2 & < 1 year & 10 & $19 \%$ \\
3 & 1-2 years & 5 & $10 \%$ \\
4 & 3-5 years & 2 & $4 \%$ \\
5 & $>$ five years & 0 & $0 \%$ \\
\hline & Total & 52 & $100 \% \%$ \\
\hline
\end{tabular}

Statistic

Min Value

Max Value

Mean

$150 \%$

Variance

$069 \%$

Standard Deviation

0.83

Total Responses

29. How long have you used DeviantArt?

\begin{tabular}{|c|l|c|c|c|}
\hline$\#$ & Answer & & Response & $\%$ \\
\hline 1 & Never & 50 & $98 \%$ \\
2 & $<1$ year & 0 & $0 \%$ \\
3 & $1-2$ years & 0 & $0 \%$ \\
4 & $3-5$ years & 0 & $0 \%$ \\
5 & $>$ five years & 1 & $2 \%$ \\
\hline & Total & 51 & $100 \% \%$ \\
\hline
\end{tabular}

Statistic

Value

Min Value

Max Value

Mean

Variance

$031 \%$

Standard Deviation

0.56

Total Responses 


\section{How long have you used LiveJournal?}

\begin{tabular}{|c|l|c|c|c|}
\hline$\#$ & Answer & & Response & $\%$ \\
\hline 1 & Never & 51 & $98 \%$ \\
2 & $<1$ year & 0 & $0 \%$ \\
3 & $1-2$ years & 0 & $0 \%$ \\
4 & $3-5$ years & 1 & $2 \%$ \\
5 & $>5$ years & 0 & $0 \%$ \\
\hline & Total & 52 & $100 \% \%$ \\
\hline
\end{tabular}

Statistic

Min Value

Max Value

Mean

Variance

$017 \%$

Standard Deviation

\section{How long have you used Tagged?}

\begin{tabular}{|c|l|c|c|c|}
\hline$\#$ & Answer & Response & $\%$ \\
\hline 1 & Never & 52 & $100 \% \%$ \\
2 & $<1$ year & 0 & $0 \%$ \\
3 & $1-2$ years & 0 & $0 \%$ \\
4 & $3-5$ years & 0 & $0 \%$ \\
5 & $>5$ years & 0 & $0 \%$ \\
\hline & Total & 52 & $100 \% \%$ \\
\hline
\end{tabular}

Min Value

Max Value

Mean

Variance

$00 \%$

Standard Deviation

$00 \%$

Total Responses 


\section{How long have you used Orkut?}

\begin{tabular}{|c|l|c|c|c|}
\hline$\#$ & Answer & Response & $\%$ \\
\hline 1 & Never & 52 & $100 \% \%$ \\
2 & $<1$ year & 0 & $0 \%$ \\
3 & $1-2$ years & 0 & $0 \%$ \\
4 & $3-5$ years & 0 & $0 \%$ \\
5 & $>5$ years & 0 & $0 \%$ \\
\hline & Total & 52 & $100 \% \%$ \\
\hline
\end{tabular}

Statistic

Min Value

Max Value

Mean

Variance

Standard Deviation

Total Responses

\section{How long have you used CafeMom?}

\begin{tabular}{|c|l|c|c|c|}
\hline$\#$ & Answer & Response & $\%$ \\
\hline 1 & Never & 52 & $100 \% \%$ \\
2 & $<1$ year & 0 & $0 \%$ \\
3 & 1-2 years & 0 & $0 \%$ \\
4 & 3-5 years & 0 & $0 \%$ \\
5 & $>$ five years & 0 & $0 \%$ \\
\hline & Total & 52 & $100 \% \%$ \\
\hline
\end{tabular}

Min Value

Max Value

Mean

$10 \%$

Variance

$00 \%$

Standard Deviation

$00 \%$

Total Responses 


\section{How long have you used Ning?}

\begin{tabular}{|c|l|c|c|c|}
\hline$\#$ & Answer & & Response & $\%$ \\
\hline 1 & Never & 47 & $98 \%$ \\
2 & < 1 year & & 0 & $0 \%$ \\
3 & 1-2 years & 0 & $0 \%$ \\
4 & 4-5 years & 0 & $0 \%$ \\
5 & $>$ five years & 1 & $2 \%$ \\
\hline & Total & $48 \%$ & $100 \% \%$ \\
\hline
\end{tabular}

Statistic

Min Value

Max Value

Mean

$18 \%$

Variance

Standard Deviation

$058 \%$

Total Responses

\section{How long have you used Meetup?}

\begin{tabular}{|c|l|c|c|c|}
\hline$\#$ & Answer & Response & $\%$ \\
\hline 1 & Never & 51 & $100 \% \%$ \\
2 & $<1$ year & 0 & $0 \%$ \\
3 & 1-2 years & 0 & $0 \%$ \\
4 & 3-5 years & 0 & $0 \%$ \\
5 & $>$ five years & 0 & $0 \%$ \\
\hline & Total & 51 & $100 \%$ \\
\hline
\end{tabular}

\section{Statistic}

Min Value

Max Value

Mean

Variance

Standard Deviation

Total Responses
Value

$10 \%$

$00 \%$

$00 \%$ 


\section{How long have you used MyLife?}

\begin{tabular}{|c|l|c|c|c|}
\hline$\#$ & Answer & Response & $\%$ \\
\hline 1 & Never & $48 \%$ & $100 \% \%$ \\
2 & < 1 year & 0 & $0 \%$ \\
3 & 1-2 years & 0 & $0 \%$ \\
4 & 3-5 years & 0 & $0 \%$ \\
5 & $>$ five years & 0 & $0 \%$ \\
\hline & Total & $48 \%$ & $100 \% \%$ \\
\hline
\end{tabular}

Statistic

Min Value

Max Value

Mean

Variance

Standard Deviation

Total Responses

\section{How long have you used Ask.fm?}

\begin{tabular}{|c|l|c|c|c|}
\hline$\#$ & Answer & & Response & $\%$ \\
\hline 1 & Never & $48 \%$ & $94 \%$ \\
2 & $<1$ year & 3 & $6 \%$ \\
3 & $1-2$ years & 0 & $0 \%$ \\
4 & $3-5$ years & 0 & $0 \%$ \\
5 & $>$ five years & 0 & $0 \%$ \\
\hline & Total & 51 & $100 \%$ \\
\hline
\end{tabular}

Min Value

Max Value

Mean

Variance

$06 \%$

Standard Deviation

$024 \%$

Total Responses 


\begin{tabular}{|c|c|c|c|}
\hline \# & Answer & Response & $\%$ \\
\hline 1 & $\begin{array}{l}\text { decrease } \\
\text { significantly }\end{array}$ & 0 & $0 \%$ \\
\hline 2 & $\begin{array}{l}\text { decrease } \\
\text { slightly }\end{array}$ & 3 & $6 \%$ \\
\hline 3 & $\begin{array}{l}\text { remain the } \\
\text { same }\end{array}$ & 38 & $73 \%$ \\
\hline 4 & $\begin{array}{l}\text { increase } \\
\text { slightly }\end{array}$ & 8 & $15 \%$ \\
\hline \multirow[t]{2}{*}{5} & $\begin{array}{l}\text { increase } \\
\text { significantly }\end{array}$ & 3 & $6 \%$ \\
\hline & Total & 52 & $100 \% \%$ \\
\hline
\end{tabular}

\section{If you Currently DO NOT use social media in the classroom, how} likely are you to start using FACEBOOK within the next two-years?

\begin{tabular}{|c|l|c|c|c|}
\hline$\#$ & Answer & & Response & $\%$ \\
\hline 1 & Will not use & & 21 & $48 \% \%$ \\
\hline 2 & only if I have & too & 10 & $23 \%$ \\
\hline 3 & Undecided & probably will & 12 & $27 \%$ \\
\hline 4 & use & definitely will & 1 & $2 \%$ \\
\hline 5 & use & 0 & $0 \%$ \\
\hline & Total & 44 & $100 \%$ \\
\hline
\end{tabular}




\section{Statistic}

Min Value

Max Value

Mean

Variance

0.83

Standard Deviation

0.91

Total Responses

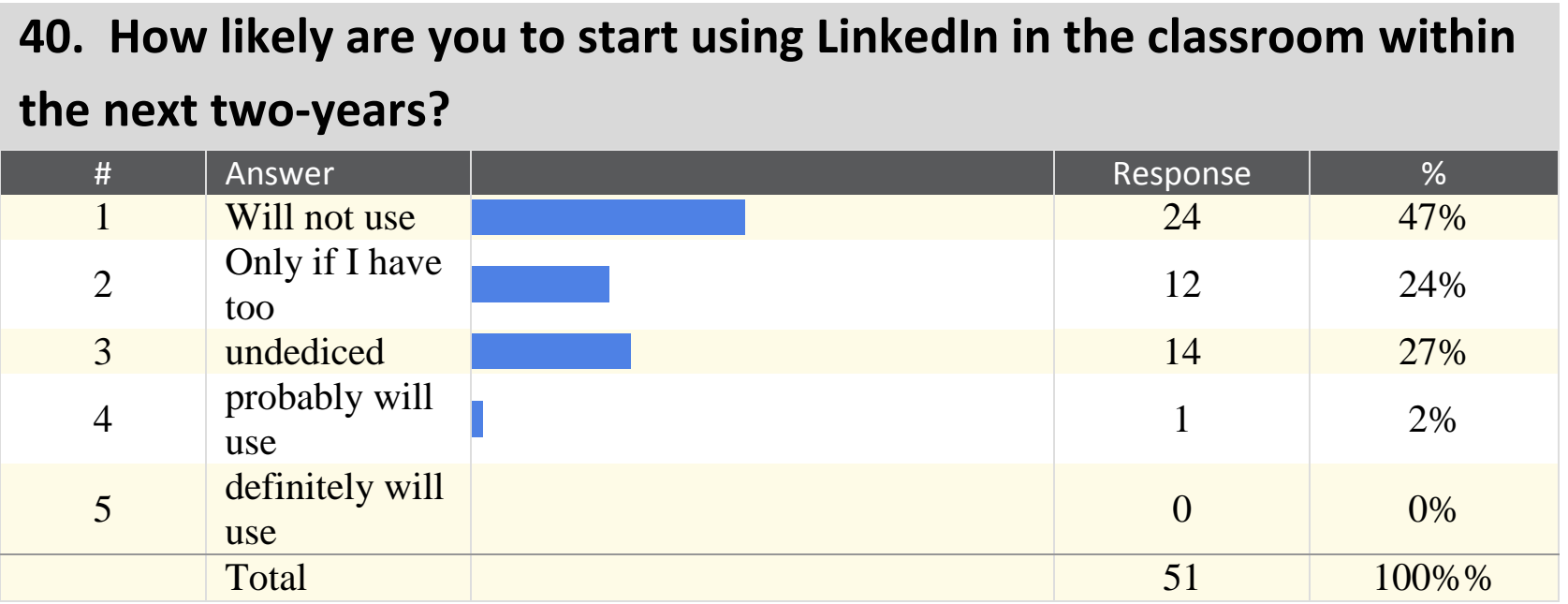

Min Value

Max Value

Mean

Variance

Standard Deviation

41. How likely are you to start using Twitter in the classroom in the
next two years?
\begin{tabular}{|c|l|c|c|c|}
$\#$ & Answer & & Response & $\%$ \\
\hline 1 & Will not use & 28 & $55 \%$ \\
2 & only if I have & 12 & $24 \%$ \\
3 & too & 7 & $14 \%$ \\
4 & Undecided & 3 & $6 \%$ \\
\hline 5 & probably will & use & & $2 \%$ \\
\hline & definitely will & 1 & $100 \% \%$ \\
\hline
\end{tabular}




\section{Statistic}

Min Value

Max Value

Mean

Variance

Standard Deviation

\section{How likely are you to begin using Moodle in the classroom in the} next two years?

\begin{tabular}{|c|l|c|c|c|}
\hline$\#$ & Answer & Response & $\%$ \\
\hline 1 & Will not use & 30 & $58 \%$ \\
2 & only if I have & too & 8 & $15 \%$ \\
3 & Undecided & 10 & $19 \%$ \\
4 & $\begin{array}{l}\text { Probably will } \\
\text { use }\end{array}$ & 2 & $4 \%$ \\
5 & $\begin{array}{l}\text { definitely will } \\
\text { use }\end{array}$ & 2 & $4 \%$ \\
\hline & Total & 52 & $100 \% \%$ \\
\hline
\end{tabular}

\begin{tabular}{|c|c|c|c|c|}
\hline \# & Answer & & Response & $\%$ \\
\hline 1 & \multirow{6}{*}{$\begin{array}{l}\text { Will not use } \\
\text { only if I have } \\
\text { too } \\
\text { Undecided } \\
\text { probably will } \\
\text { use } \\
\text { definitely will } \\
\text { use }\end{array}$} & & 31 & $61 \%$ \\
\hline 2 & & & 9 & $18 \%$ \\
\hline 3 & & 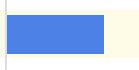 & 8 & $16 \%$ \\
\hline 4 & & I & 1 & $2 \%$ \\
\hline \multirow[t]{2}{*}{5} & & [ & 2 & $4 \%$ \\
\hline & & & 51 & $100 \% \%$ \\
\hline
\end{tabular}




\section{Statistic}

Min Value

Max Value

Mean

$171 \%$

Variance

Standard Deviation

\section{How likely are you to use MySpace in the classroom in the next} two years?

\begin{tabular}{|c|l|c|c|c|}
\hline$\#$ & Answer & Response & $\%$ \\
\hline 1 & Will not use & 35 & $67 \%$ \\
\hline 2 & only if I have & too & 11 & $21 \%$ \\
\hline 3 & Undecided & probably will & 0 & $12 \%$ \\
\hline 4 & use & & $0 \%$ \\
\hline 5 & definitely will & use & 0 & $0 \%$ \\
\hline & Total & 52 & $100 \%$ \\
\hline
\end{tabular}

Min Value

Max Value

Mean

$144 \%$

Variance

Standard Deviation

0.70

Total Responses

45. How likely are you to start using Google Plus+ in the classroom in
the next two years?
\begin{tabular}{|c|l|c|c|c|}
$\#$ & Answer & & Response & $\%$ \\
\hline 1 & Will not use & 19 & $37 \%$ \\
2 & only if I have & 7 & $14 \%$ \\
3 & too & 12 & $24 \%$ \\
4 & Undecided & probably will & 10 & $20 \%$ \\
\hline 5 & use & definitely will & 3 & $6 \%$ \\
\hline & use & 51 & $100 \% \%$ \\
\hline
\end{tabular}




\section{Statistic}

Min Value

Max Value

Mean

Variance

Standard Deviation

\section{How likely are you to start using DeviantArt in the classroom}

\section{within the next two years?}

\begin{tabular}{|c|l|c|c|c|}
\hline$\#$ & Answer & Response & $\%$ \\
\hline 1 & Will not use & & 37 & $73 \%$ \\
\hline 2 & only if I have & too & 11 & $22 \%$ \\
\hline 3 & Undecided & 3 & $6 \%$ \\
\hline 4 & probably will & use & 0 & $0 \%$ \\
\hline 5 & definitely will & use & 0 & $0 \%$ \\
\hline & Total & 51 & $100 \%$ \\
\hline
\end{tabular}

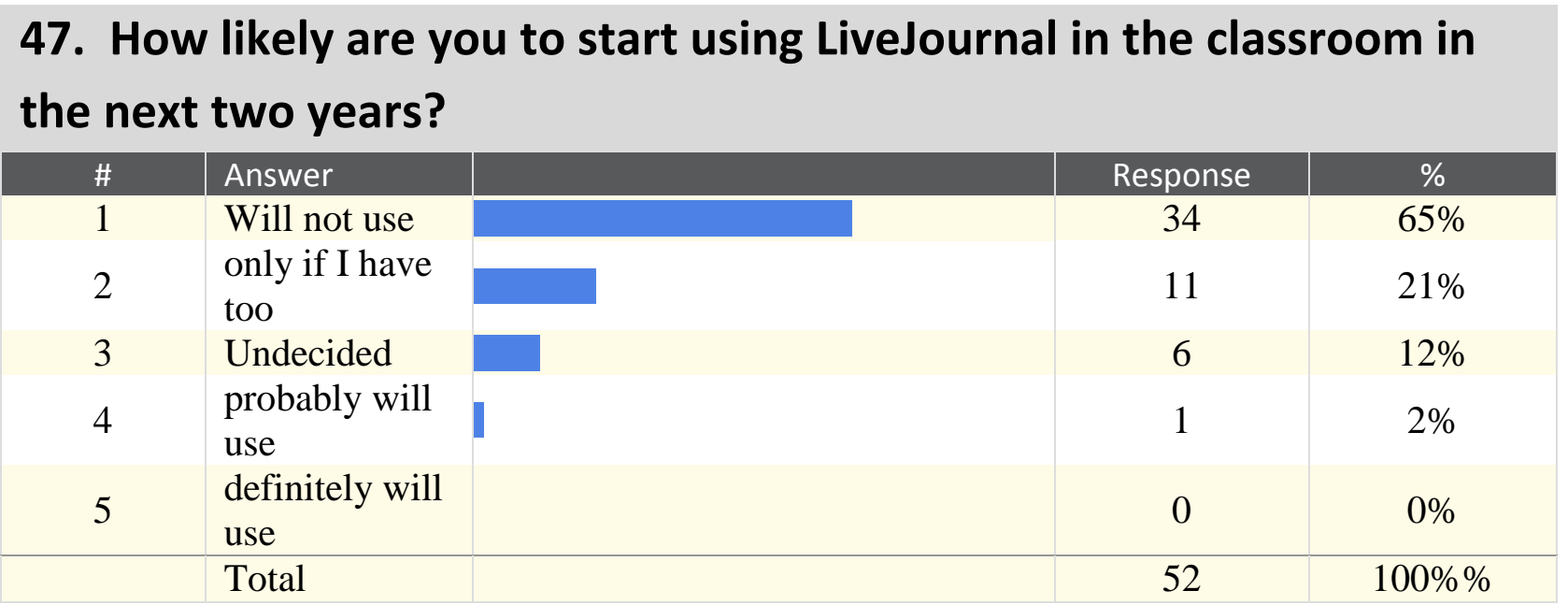




\section{Statistic}

Min Value

Max Value

Mean

$150 \%$

Variance

Standard Deviation

\begin{tabular}{|c|c|c|c|}
\hline \# & Answer & Response & $\%$ \\
\hline 1 & \multirow{6}{*}{$\begin{array}{l}\text { Will not use } \\
\text { only if I have } \\
\text { too } \\
\text { Undecided } \\
\text { probably will } \\
\text { use } \\
\text { definitely will } \\
\text { use } \\
\text { Total }\end{array}$} & 36 & $69 \%$ \\
\hline 2 & & 10 & $19 \%$ \\
\hline 3 & & 6 & $12 \%$ \\
\hline 4 & & 0 & $0 \%$ \\
\hline \multirow[t]{2}{*}{5} & & 0 & $0 \%$ \\
\hline & & 52 & $100 \% \%$ \\
\hline
\end{tabular}

Variance

\section{How likely are you to start using Orkut in the classroom in the} next two years?

\begin{tabular}{|c|l|c|c|c|}
\hline$\#$ & Answer & Response & $\%$ \\
\hline 1 & Will not use & 36 & $73 \%$ \\
2 & only if I have & & 9 & $18 \%$ \\
\hline 3 & too & Undecided & 4 & $8 \%$ \\
\hline 4 & probably will & use & 0 & $0 \%$ \\
\hline 5 & definitely will & use & 0 & $0 \%$ \\
\hline & Total & 49 & $100 \% \%$ \\
\hline
\end{tabular}




\section{Statistic}

Min Value

Max Value

Mean

Variance

Standard Deviation

\section{How likely are you to start using Ning in the classroom in the next} two years?

\begin{tabular}{|c|l|l|c|c|}
\hline$\#$ & Answer & & Response & $\%$ \\
\hline 1 & Will not use & & 37 & $76 \%$ \\
\hline 2 & only if I have & & 9 & $18 \%$ \\
\hline 3 & too & Undecided & 3 & $6 \%$ \\
\hline 4 & probably will & use & 0 & $0 \%$ \\
\hline 5 & definitely will & use & 0 & $0 \%$ \\
\hline & Total & 49 & $100 \%$ \\
\hline
\end{tabular}

\section{How likely are you to start using Meetup in the classroom in the} next two years?

\begin{tabular}{|c|l|c|c|c|}
\hline$\#$ & Answer & & Response & $\%$ \\
\hline 1 & Will not use & & 31 & $61 \%$ \\
2 & only if I have & & 10 & $20 \%$ \\
\hline 3 & too & Undecided & 9 & $18 \%$ \\
\hline 4 & probably will & use & 1 & $2 \%$ \\
\hline 5 & definitely will & use & 0 & $0 \%$ \\
\hline & Total & 51 & $100 \% \%$ \\
\hline
\end{tabular}




\section{Statistic}

Min Value

Max Value

Mean

1.61

Variance

0.72

Standard Deviation

0.85

Total Responses

\section{How likely are you to start using MyLife in the classroom in the} next two years?

\begin{tabular}{|c|l|c|c|c|}
\hline$\#$ & Answer & Response & $\%$ \\
\hline 1 & Will not use & 36 & $73 \%$ \\
\hline 2 & only if I have & too & 9 & $18 \%$ \\
\hline 3 & Undecided & & 4 & $8 \%$ \\
\hline 4 & probably will & use & 0 & $0 \%$ \\
\hline 5 & definitely will & use & 0 & $0 \%$ \\
\hline & Total & 49 & $100 \%$ \\
\hline
\end{tabular}

Min Value

Max Value

Mean

Variance

Standard Deviation

53. How likely are you to start using Ask.fm in the classroom in the
next two years?
\begin{tabular}{c|l|c|c|c|}
$\#$ & Answer & Response & $\%$ \\
\hline 1 & Will not use & 32 & $64 \%$ \\
2 & only if I have & 8 & $16 \%$ \\
3 & too & 9 & $18 \%$ \\
4 & Undecided & 1 & $2 \%$ \\
\hline 5 & probably will & use & 0 & $0 \%$ \\
\hline & definitely will & use & 50 & $100 \% \%$ \\
\hline
\end{tabular}




\section{Statistic}

Min Value

Max Value

Mean

Variance

Standard Deviation

\section{When you think about how you use social media, do you use these tools for PROFESSIONAL USE (such as with students or colleagues) or for PERSONAL use during your free time?}

\begin{tabular}{|c|l|c|c|c|}
\hline$\#$ & Answer & Response & $\%$ \\
\hline 1 & PROFESSIONAL & 15 & $33 \%$ \\
\hline 2 & PERSONAL & 31 & $67 \%$ \\
\hline & Total & 46 & $100 \% \%$ \\
\hline
\end{tabular}

\section{Statistic}

Max Value

Mean

Variance

\section{Have you ever "friended" a student on FACEBOOK?}

\begin{tabular}{|c|l|c|c|c|}
\hline$\#$ & Answer & & Response & $\%$ \\
\hline 1 & Yes & & 20 & $40 \%$ \\
2 & No & & 30 & $60 \%$ \\
\hline & Total & & 50 & $100 \% \%$ \\
\hline
\end{tabular}

\section{Statistic}

Min Value

Max Value

Mean

Variance

$024 \%$

Standard Deviation

0.49

Total Responses 


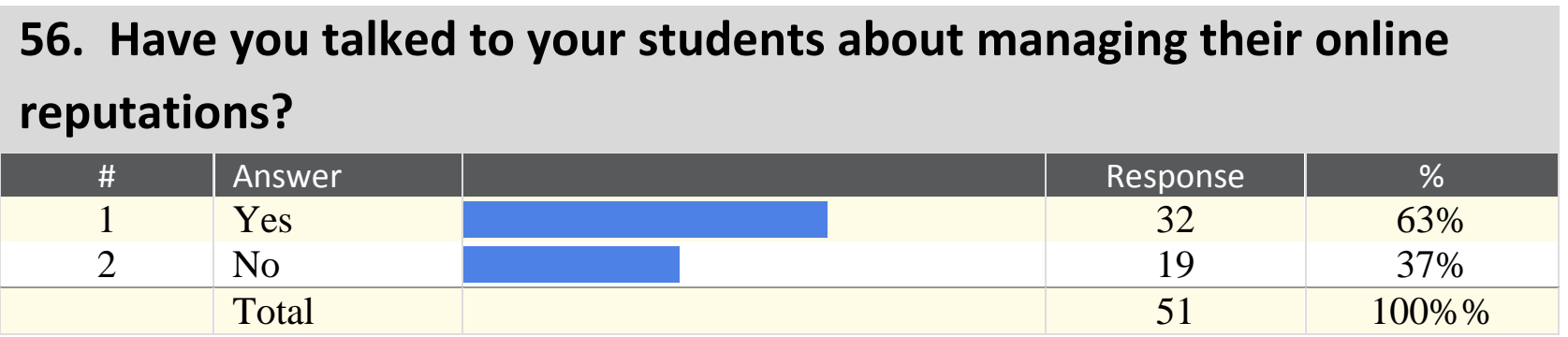

\section{Statistic}

Max Value

Mean

$024 \%$

Variance

57. Despite the benefits of social media, problems can arise when the technologies are used in an inappropriate manner or at inappropriate times. Have you encountered any issues and if so what were they?

\section{Does your institution have a social media policy?}

\begin{tabular}{|c|l|l|c|c|}
\hline$\#$ & Answer & & Response & $\%$ \\
\hline 1 & Yes & & 13 & $87 \%$ \\
2 & No & 2 & $13 \%$ \\
\hline & Total & 15 & $100 \% \%$ \\
\hline
\end{tabular}

\section{Statistic}

Mean

Variance 
59. Please provide any additional comments or anecdotes about your impressions of the role of social media in higher education (optional). 
Text Response

no comment

I believe that as educators of learners in the 21 st century we will have to embrace social media to reach all learners.

I use Facebook groups for students working on projects or in some classes where we need to keep in contact but don't necessarily need an entire course management system. It works very well. Students have easy access and get their messages quickly.

I really don't like using social media in the classroom; I feel it provides an excuse for sutdents to browse facebook and others durring classtime and at other times when the really need to be focusing on other matters

Social media provides an excellent opportunity to "get to know" online students in a more informal way. I use it to push content from WSJ, HBJ, and other business journals for students to read. For the marketing classes, it is required that students create a FB page for a local business or organization.

I'm aware that many faculty use social media for professional purposes, and I assume that more faculty will do so in the future.

At this time, I feel that social media has the (deserved) reputation as being silly and trivial. It is very asual in its use and implys a casual relationship between users. As a professor, my relationship with studnts is not and should not be that casual.

Employers are using them and students need to have profiles with several of them (such as Linkedin) to connect with potential employers.

I think it could be a useful tool, given proper training for students and faculty.

I use a facebook group for my labs and post on assignments on google+, sometimes former students friend my on facebook which I usually accept. I once had a student calling in sick who posted vacation pictures openly on facebook, which another student told me.

Don't even know what most of these are. No idea how they could be used in an academic setting if they are SOCIAL media.

Social media have their place, but too many people get addicted to them.

I keep a Facebook page for a student organization that I advise and posts events on it, but I don't use it in the classroom.

It's a key to the future. Give me six months to research (on Twitter) the most effective ways to use it in the classroom, and get administrative "APPROVAL", and I would run with it (and be happy to share the info). Some years ago (maybe 5), I opened up a MYSPACE Page for a class. I intended to use it as a bulletin board for assignments/deadlines. This was when a majority of students used MYSPACE. I knew that they were on MYSPACE a couple of times a day, but were not checking their WVUP email on any regular basis. The administration called the chair of my department and had a totally incorrect idea of what I was trying to do. (this was before the social media policy was created). At the last Adjunct conference Adjuncts were complaining that they had no way to get in contact with each other. I had just presented a class on how to do research on Twitter, so I created a hashtag for WVUPadj. I was congratulated by those in power, and it was announced at the luncheon. (Sat.). Monday, the same person called me into her office to tell me I had violated the social media policy, and i needed to delete the hashtag. I explained that I did not think you could "delete" a hashtag. The institution does not encourage the use of social media. and many of the faculty members are not very tech savvy. or interested in redesigning their curriculum. When the next generation is running things, we will see a quantum leap in the use of social media in the classroom. . Great 
topic for a dissertation.

I have tried to inspire blogs on MOODLE but students do not participate. Almost everyone texts and it is easier. Students like nature, follow the path of least resistance.

I'm a fan of technology, but prefer to only use media attached to the school server, such as google + which is clearly available to us all

Regarding the question "Have you ever "friended" a student on FACEBOOK? " I have never sought to add a student as a friend, but I have been added by students.

I find it useful to see what the student climate is.

Students and professors have a professional relationship; there is no room for social media.

I use OpenClass and have posted on the timeline there; but I have students who don't use the information or who never access it.

I do not "friend" students; however, I do accept friend requests.

My outsider's view is that the "addictive" use of social media dimishes the development of listening, analysizing, and critical thinking skills.

I use technology like MyMathLab extensively and I have a website under Google sites I use to provide students access to copies of my syllabus and instructional videos. But I do not use social media.

Social media can be used to enhance learning and to reach different styles of learning Posting common information, such as take-home quizzes and syllabi, on facebook provides students with access to these materials without worrying about keeping a hard copy. It also saves paper.

I do not believe it belongs in the classroom because of risk of violations of confidentiality. I know many people use Facebook in the classroom because the students already use it and are comfortable with it, but students need to be pushed to learn / find information that may not be available in the realm of social media. I don't feel the need to cave to my students' every desire. I don't feel we're helping prepare them for the professional world by telling them that since they're all addicted to Facebook anyway, we're going to go ahead and just make that our primary teaching tool. They need to be able to sit in meetings or at desks at work and actually pay attention to people/issues that exist in the real world. 
Survey Two

\section{Appendix E}

My Report

Last Modified: 03/15/2014

1. What is your role in higher education?

\begin{tabular}{|c|l|c|c|c|}
\hline$\#$ & Answer & Response & $\%$ \\
\hline 1 & Instructor & 12 & $38 \%$ \\
2 & Associate & 4 & $13 \%$ \\
& Professor & & \\
3 & Assistant & 7 & $22 \%$ \\
4 & Professor & 7 & $22 \%$ \\
5 & Full Professor & Instructional & 2 & $6 \%$ \\
\hline & Specialist & 32 & $100 \% \%$ \\
\hline
\end{tabular}

Min Value

Max Value

Mean

$247 \%$

Variance

$187 \%$

Standard Deviation

$137 \%$

Total Responses 


\section{How many years have you worked in higher education?}

\section{Text Response}

2

20

10

13

4

17

15

29

3

27

31

5

35

2.5

13

10 years

15 years

10

2

6

$+10$

7

42

5

6

7

I have worked two and a half years as an adjunct.

11

2

10

23

5 


\section{What is your employment designation?}

\begin{tabular}{|c|l|l|c|c|}
\hline$\#$ & Answer & & Response & $\%$ \\
\hline 1 & term & 19 & $59 \%$ \\
2 & tenure & 9 & $28 \%$ \\
3 & tenure track & 0 & $0 \%$ \\
\hline 4 & instructional & 4 & $13 \%$ \\
\hline & specialist & 32 & $100 \% \%$ \\
\hline
\end{tabular}

Statistic

Min Value

Max Value

Mean

$166 \%$

Variance

1.01

Standard Deviation

\section{What is your gender?}

\begin{tabular}{|c|l|c|c|c|}
\hline$\#$ & Answer & & Response & $\%$ \\
\hline 1 & Male & & 11 & $34 \%$ \\
2 & Female & & 21 & $66 \%$ \\
\hline & Total & & 32 & $100 \% \%$ \\
\hline
\end{tabular}

\section{Statistic}

Min Value

Max Value

Mean

$166 \%$

Variance

Standard Deviation

\section{Are you}

\begin{tabular}{|c|l|c|c|c|}
\hline$\#$ & Answer & & Response & $\%$ \\
\hline 1 & Full time & & 24 & $77 \%$ \\
2 & Adjunct & & 7 & $23 \%$ \\
\hline & Total & 31 & $100 \% \%$ \\
\hline
\end{tabular}




\section{Statistic}

Min Value

Max Value

$123 \%$

Mean

$018 \%$

Variance

Standard Deviation

6. Do you use social media, then please fill out the next question, but if your answer is no then you will be directed to the end of the survey.

\begin{tabular}{|c|l|c|c|c|}
\hline$\#$ & Answer & & Response & $\%$ \\
\hline 1 & yes & & 25 & $78 \%$ \\
2 & No & & 7 & $22 \%$ \\
\hline & Total & & 32 & $100 \% \%$ \\
\hline
\end{tabular}

\section{Statistic}

Min Value

Max Value

Mean

Variance

Standard Deviation

Total Responses

\section{Using the following numbers as hours in a week, approximately how much time do you spend on the following social media?}

\begin{tabular}{|c|c|c|c|c|c|c|}
\hline \# & Answer & Min Value & Max Value & $\begin{array}{c}\text { Average } \\
\text { Value }\end{array}$ & $\begin{array}{l}\text { Standard } \\
\text { Deviation }\end{array}$ & Responses \\
\hline 1 & Facebook & $10 \%$ & $200 \%$ & $594 \%$ & $57 \%$ & 18 \\
\hline 2 & LinkedIn & $10 \%$ & $30 \%$ & 1.56 & 0.88 & 9 \\
\hline 3 & Twitter & $00 \%$ & $30 \%$ & $167 \%$ & $137 \%$ & 6 \\
\hline 4 & Moodle & $10 \%$ & $150 \%$ & $80 \%$ & $990 \%$ & 2 \\
\hline 5 & Pinterest & $00 \%$ & $100 \% \%$ & $322 \%$ & $346 \%$ & 9 \\
\hline 6 & $\begin{array}{l}\text { Google } \\
\text { Plus+ }\end{array}$ & $10 \%$ & $180 \%$ & 5.70 & 5.77 & 10 \\
\hline
\end{tabular}




\section{Are you aware when you post on social media (Facebook) to your} friends, if a friend "likes" what you post then all of their friends will see it (and it can snowball from there)?

\begin{tabular}{|c|l|c|c|c|}
\hline$\#$ & Answer & & Response & $\%$ \\
\hline 1 & Yes & & 19 & $90 \%$ \\
2 & No & & 2 & $10 \%$ \\
\hline & Total & & 21 & $100 \% \%$ \\
\hline
\end{tabular}

Statistic

Min Value

Max Value

Mean

Variance

Standard Deviation

Total Responses
Value

0.30

21 


\section{What is your definition of professional use of social media?}

\section{Text Response}

to make accessible digitally to students course material that would normally be printed on paper Don't put anything in writing that you wouldn't want to see as headlines in the newspaper Used for communiication with my students and colleagues

Using social media to enhance teaching, networking and any other professional responsibilties in education, professional use would be for research, imparting knowledge, and receiving research and knowledge

Use intended as the sharing of information with colleagues and students

To provide communication within a business

Sharing business journal posts with students, sharing job search info with current and former students

Using the media in a respectful, polite and professional way being conscious of the fact what is shared cannot be retrieved. Teachers of higher education need to be cautious of the potential issues that can present by "being friends" with students. I do not think this is professional.

For me, "professional use" connotes a purpose different than its social purposes. In other words, I do not think that most people are using social media for professional purposes.

Using social media in a manner that shares personal information with others while still maintaining social media etiquette

Twitter: I follow those designated in Educational Technology EMAIL I did not answer the question above. I do not use Facebook

Keeping it work and career related. E.g. No pics of kids, dogs, cats

Being responsible and think before you post

Collaboration and information

Observe current trends, social topics, opinions, gather ideas

Any social media in any form that allows a faculty member to fulfill his/her job duties

Promotion of my business 


\section{Check all that you consider to be professional connections on} social media.

\begin{tabular}{|c|c|c|c|}
\hline \# & Answer & Response & $\%$ \\
\hline 1 & $\begin{array}{l}\text { Business } \\
\text { Acquaintances }\end{array}$ & 14 & $64 \%$ \\
\hline 2 & $\begin{array}{l}\text { Teaching } \\
\text { colleagues }\end{array}$ & 19 & $86 \%$ \\
\hline 3 & students & 14 & $64 \%$ \\
\hline 4 & family & 4 & $18 \%$ \\
\hline 5 & friends & 4 & $18 \%$ \\
\hline 6 & $\begin{array}{l}\text { other please } \\
\text { identify }\end{array}$ & 2 & $9 \%$ \\
\hline
\end{tabular}

other please identify

Twitter: as mentioned above

Statistic

Min Value

Max Value

Total Responses

\section{Check all that you consider to be personal connections only.}

\begin{tabular}{|c|l|c|c|c|}
\hline$\#$ & Answer & Response & $\%$ \\
\hline 1 & $\begin{array}{l}\text { Business } \\
\text { Acquaintances }\end{array}$ & 1 & $5 \%$ \\
\hline 2 & $\begin{array}{l}\text { Teaching } \\
\text { Colleagues }\end{array}$ & 0 & $0 \%$ \\
3 & students & 1 & $5 \%$ \\
4 & family & 21 & $100 \% \%$ \\
5 & friends & 21 & $100 \% \%$ \\
6 & other please & & 2 & $10 \%$ \\
\hline
\end{tabular}

\section{other please identify}

graduates

Literary Salon 
Statistic

Max Value

Total Responses

\section{Check all that apply regarding friending students on social media.}

\begin{tabular}{|c|c|c|c|}
\hline$\#$ & Answer & Response & $\%$ \\
\hline 1 & $\begin{array}{l}\text { I have friends } \\
\text { that are } \\
\text { students on } \\
\text { social media }\end{array}$ & 9 & $47 \%$ \\
\hline 2 & $\begin{array}{l}\text { I have current } \\
\text { students that } \\
\text { are friends on } \\
\text { social media }\end{array}$ & 7 & $37 \%$ \\
\hline 3 & $\begin{array}{l}\text { I initiate } \\
\text { friending my } \\
\text { students }\end{array}$ & 1 & $5 \%$ \\
\hline 4 & $\begin{array}{l}\text { I friend } \\
\text { students that } \\
\text { ask me to } \\
\text { friend them } \\
\text { first on social } \\
\text { media }\end{array}$ & 4 & $21 \%$ \\
\hline 5 & $\begin{array}{l}\text { I never friend } \\
\text { current } \\
\text { students on } \\
\text { social media }\end{array}$ & 8 & $42 \%$ \\
\hline 6 & $\begin{array}{l}\text { I have } \\
\text { defriended } \\
\text { students that } \\
\text { became } \\
\text { "current" } \\
\text { students on } \\
\text { social media }\end{array}$ & 3 & $16 \%$ \\
\hline
\end{tabular}




\section{If you currently have students that are friends on social media, check all of the social media that applies.}

\begin{tabular}{|c|l|c|c|c|}
\hline$\#$ & Answer & & Response & $\%$ \\
\hline 1 & Facebbook & 11 & $69 \%$ \\
2 & LinkedIn & & 1 & $6 \%$ \\
3 & Twitter & 0 & $0 \%$ \\
4 & Moodle & 0 & $0 \%$ \\
5 & Pinterest & & 0 & $0 \%$ \\
6 & Google Plus+ & & 4 & $25 \%$ \\
\hline & Total & 16 & $100 \% \%$ \\
\hline
\end{tabular}

Mean

\section{Have you ever answered questions or posted things on social} media in response to the following questions (check all that apply)?

\begin{tabular}{|l|l|l|l|l|}
\hline$\#$ & Answer & & Response & $\%$ \\
\hline \multirow{3}{*}{2} & $\begin{array}{l}\text { Can you tell } \\
\text { me what my } \\
\text { grades are? }\end{array}$ & $\begin{array}{l}\text { Can you help } \\
\text { me with this } \\
\text { class? }\end{array}$ & 1 & $33 \%$ \\
\hline \multirow{2}{*}{$\begin{array}{l}\text { Can you } \\
\text { advise me } \\
\text { regarding a } \\
\text { situation } \\
\text { related to } \\
\text { school? }\end{array}$} & & 3 & $100 \% \%$ \\
\hline
\end{tabular}




\section{Have you ever posted something on social media that you regretted posting later?}

\begin{tabular}{|c|l|r|r|c|}
\hline$\#$ & Answer & Response & $\%$ \\
\hline 1 & Yes (PLEASE & 2 & $10 \%$ \\
\hline 2 & IDENTIFY) & No & 19 & $90 \%$ \\
\hline & Total & 21 & $100 \% \%$ \\
\hline
\end{tabular}

\section{Yes (PLEASE IDENTIFY)}

A reaction to a news story

If I make spelling mistakes.

\section{Statistic}

Min Value

Max Value

Mean

Variance

$09 \%$

Standard Deviation

0.30

Total Responses

\section{Do you know what the social media policy is at this college?}

\begin{tabular}{|l|l|l|c|c|}
\hline$\#$ & Answer & & Response & $\%$ \\
\hline 1 & Yes & 3 & $14 \%$ \\
2 & no & 6 & $27 \%$ \\
\hline 3 & don't know if & 13 & $59 \%$ \\
\hline & we have one & 22 & $100 \% \%$ \\
\hline
\end{tabular}

\section{Statistic}

Min Value

Max Value

Mean

2.45

Variance

$055 \%$

Standard Deviation

0.74

Total Responses 


\section{Are you aware of the Family Educational Rights of Privacy Act}

(FERPA) and how this act might affect communications between students and faculty when using social media?

\begin{tabular}{|c|l|c|c|c|}
\hline$\#$ & Answer & & Response & $\%$ \\
\hline 1 & Yes & & 16 & $73 \%$ \\
2 & No & 6 & $27 \%$ \\
\hline & Total & & 22 & $100 \% \%$ \\
\hline
\end{tabular}

Statistic

Min Value

Max Value

Mean

Variance

Standard Deviation

Total Responses
Value

$127 \%$

$021 \%$

$046 \%$

22 


\section{Please share any antidotes or other information you think would be helpful with this survey (bad experiences or good experiences using social media). Thank you in advance for participating in this survey.} Text Response

Question 7 only will allow one selection

I am aware of Ferpa but do not post to Facebook; more observer, learner; through years I know that comments may be misinterpreted.

We have a social media policy in my division. One student informed me that another student was discussing clinical and perceived discrimination on FB. Since the word "discrimination" was used, it went to the Social Justice Committee but since it was posted on a social media, the APG committee had to determine whether or not the student violated the social media policy. The student was extremely vague in the FB posts \& found not to be in violation of the policy, and after a conference with instructors and the campus counselor, the student did not pursue any discrimination claims.

The nursing department had an interesting situation about a student who failed out of the program. Comments were made without giving the students name but many know the identity of the student. I understood there was potential or threatened ramifications as a result of the situation. This happened before I joined the ranks but I was aware of the situation. I do not have proof but I believe both of the instructors involved still are still actively into social media. One is not on FB but Tweeter.

I communicate about grades and advising through email. I don't consider email as "social media."

LinkedIn and Google + doesn't have "friends". I do not see any differentiation between current and former students. Couldn't really answer this question.

Not all of the buttons work correctly for multiple answers

19. Can I please have your name so I can contact you if you qualify for the third and final survey. Your name will not be given out in any public information. All questions will be tabulated in the aggregate for sharing without personal information being attached. 